\title{
Attention to dividends, inattention to earnings?
}

\author{
Charles G. Ham ${ }^{1}$ D $\cdot$ Zachary R. Kaplan ${ }^{1} \cdot$ Steven Utke ${ }^{2}$
}

Accepted: 3 September 2021 / Published online: 26 November 2021

(c) The Author(s) 2021

\begin{abstract}
We examine whether dividends serve as substitutes or complements to accounting information in firm valuation. Consistent with dividends substituting for earnings information, we find that dividend paying firms have $11 \%-15 \%$ lower earnings response coefficients (ERCs) than non-payers. We find more substitution when the dividend provides a stronger signal of permanent earnings: when the firm is less likely to cut the dividend, when the firm is likely to fund the dividend out of earnings rather than cash reserves, or when the dividend is larger. We then show that dividend payers have lower absolute returns, less trading volume, and fewer analyst forecasts at the earnings announcement (EA), suggesting that dividend payers attract less attention to their less informative EAs. Finally, we show that the lower EA attention translates into less earnings management and fewer earnings-related disclosures for dividend payers relative to non-payers. Collectively, this evidence suggests that dividends supply information about permanent earnings and, although costly, could be an efficient way for some firms to satisfy investors' demand for earnings information.
\end{abstract}

Keywords Dividends · Information environment · Earnings announcements · Earnings management

JEL classification M41 - G35

Charles G. Ham

cham@wustl.edu

Zachary R. Kaplan

zrkaplan@wustl.edu

Steven Utke

sutke@uconn.edu

1 Olin Business School, Washington University in St. Louis, One Brookings Drive, St. Louis, MO 63130, USA

2 University of Connecticut, Storrs, CT, USA 


\section{Introduction}

We examine whether dividends serve as substitutes or complements to accounting information in firm valuation. Because managers implicitly commit to maintaining dividends, we hypothesize that the dividend level supplies information about the level of permanent earnings and thereby decreases the informativeness of other sources of earnings information, such as earnings announcements (EAs). ${ }^{1}$ Thus, we expect that investors update their expectations less in response to each earnings realization for dividend paying firms. Although we predict that dividends supply earnings information (leading to substitution), several dividend theories suggest a complementary or nonexistent relation between dividends and earnings news. For example, if dividends primarily resolve agency conflicts (e.g., Easterbrook 1984; Jensen 1986), then they reduce the value of the firm one-for-one with cash payout (e.g., Penman and Sougiannis 1997) but are uninformative about future earnings. Alternatively, if dividends signal firm maturity and thus impact valuation by reducing the rate at which investors discount future earnings (e.g., Chen et al. 2007; Skinner and Soltes 2011; Michaely et al. 2021), the lower discount rate should increase investors' reaction to earnings surprises of dividend payers.

Our primary analysis compares the valuation impact of earnings surprises for dividend payers versus non-payers. Substitution implies a lower valuation response (i.e., response per unit of earnings news) for payers. ${ }^{2}$ We find that dividend payers have 11\%-15\% lower earnings response coefficients (ERCs), consistent with substitution. Several features of our analyses, along with additional tests, suggest that observable differences between payers and non-payers do not drive our results. First, we use two matching techniques-propensity score matching and entropy balancing-to match payers to non-payers that are similar on firm attributes previously shown to affect dividend payments. Second, within the sample of payers, we find a lower reaction to earnings surprises when the firm announces the dividend closer in event time to the EA, consistent with more timely information leading to greater substitution. Third, we show the converse: smaller reactions to dividend changes occurring closer in event time to the EA.

Analysis on the mechanisms driving the substitution effect provides additional support for our hypothesis. First, we find less persistent earnings surprises for payers relative to non-payers, consistent with dividends affecting ERCs by increasing the information about future earnings in pre-EA expectations. Although dividend payers have more persistent earnings levels (Skinner and Soltes 2011), dividends supply information about persistent earnings (e.g., DeAngelo et al. 1992; Fama and French 1998; Guay and Harford 2000) which should substitute for the persistent earnings information otherwise revealed to investors at the EA (i.e., in the surprise).

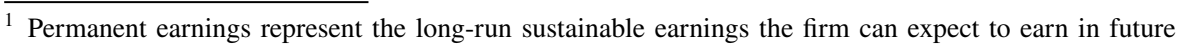
periods.

2 Importantly, dividend payers' managing earnings less - as documented in our second set of testsshould lead to stronger, not weaker, investor reactions to EAs (e.g., Bartov et al. 2002; Gleason and Mills 2008; Kim et al. 2021).
} 
Second, across three measures - trading volume, return volatility, and analyst forecasts-we show that market participants respond 3\%-8\% less to the EA for dividend payers relative to non-payers, consistent with market participants being less attentive to these less persistent earnings surprises. Third, in untabulated analyses we find no differences in post-EA drift between payers and non-payers, which is also consistent with our ERC results arising because of differences in informativeness rather than underreaction. Taken together, our results indicate that the weaker valuation implications of EAs for dividend payers lead to less investor attention, consistent with a rational shift in investor attention (e.g., Blankespoor et al. 2020).

Our next set of analyses explores heterogeneity in the substitutability of dividend and earnings information. We expect greater (smaller) reductions in ERCs for firms that convey more (less) permanent earnings information through the dividend. We explore three sources of heterogeneity. First, for firms with large cash balances, we argue that dividends do not necessarily provide a signal of permanent earnings, because the firm can sustain the dividend through existing cash rather than future earnings (e.g., Kaplan and Perez-Cavazos 2021). ${ }^{3}$ Second, we argue that firms that are likely to cut the dividend convey less permanent earnings information through their dividend because they are unable to make a commitment to sustain the dividend permanently. Consistent with both arguments, we find our results are attenuated for firms with high cash holdings and firms more likely to cut the dividend.

Third, we contrast the substitution effect for dividends and repurchases, and examine heterogeneity arising from the size of the payout (i.e., yield). For either form of payout, if yield represents permanent earnings and is thus valued by investors as a perpetuity, a larger yield will explain a relatively larger portion of valuation, leading to greater substitution with earnings information. While dividends and repurchases are similar from a capital structure perspective (i.e., both remove cash from the control of managers), from an information perspective they differ because dividends are highly persistent whereas repurchases are transitory (e.g., Guay and Harford 2000). We thus expect stronger substitution effects for dividends than for repurchases because dividends distribute permanent as opposed to transitory earnings. ${ }^{4}$ As expected, we find that substitution increases in dividend yield, but not repurchase yield. This result holds both (i) when we contrast firms that only pay dividends with firms that only repurchase, and (ii) within firms that pay dividends and repurchase, exploiting variation in the yield.

After documenting that dividends reduce the reaction to EAs, our final set of tests examines the association between dividend paying and firm behavior. Because market participants focus less on the earnings of dividend payers, we predict that managers will also focus less on earnings, leading to less earnings manipulation

\footnotetext{
3 For example, as of December 31, 2020, Microsoft had \$132 billion of cash and an annual dividend of $\$ 16.9$ billion ( $\$ 2.24$ per share $* 7.54$ billion shares outstanding), giving it sufficient cash to fund its dividend for more than seven years without additional cash inflows.

4 An alternative theory that would predict a lack of information effects for both repurchases and dividends is that dividends are changed infrequently because they are a historical artifact of past payout choices (e.g., Skinner 2008).
} 
(e.g., Stein 1989). We focus on meet or beat behavior because managers sacrifice resources to meet or beat and face career concerns for missing targets (Matsunaga and Park 2001; Graham et al. 2005; Bird et al. 2019). Consistent with our expectations, payers just meet or beat (miss) analysts' earnings estimates less (more) frequently than non-payers.

We link the meet or beat results to earnings and expectations management by showing that payers are less likely to (i) manage revenues, receivables, and R\&D to just meet or beat analysts' forecasts (e.g., Bhojraj et al. 2009; Stubben 2010), and (ii) report non-GAAP earnings, which affect the items included by I/B/E/S in actual earnings (Christensen et al. 2011) and help the firm exceed analysts' forecasts. Additionally, we show that managers of dividend payers are less likely to provide earnings guidance, potentially making analysts' forecasts more difficult to narrowly exceed (e.g., Ajinkya and Gift 1984; Skinner 1994). Finally, examining conference call content, we find that firms are more likely to discuss earnings when just meeting or beating expectations, but this effect is attenuated for payers. This supports our view that managers of payers focus less on reported earnings thresholds.

Our study makes several contributions. First, we answer the call for additional research that considers the interdependencies between firm decisions and the information environment (Healy and Palepu 2001; Beyer et al. 2010). We demonstrate that the presence of a dividend affects the supply and demand for earnings information, documenting a substitution effect. We find that managers substitute away from earnings management when they pay dividends. Many researchers and practitioners lament that the "numbers game" leads to a short-term earnings focus by managers (e.g., Levitt 1998; Matsunaga and Park 2001; Dimon and Buffett 2018). Our study suggests that providing an alternative valuation metric such as a dividend can alleviate some of these costs by enriching the information environment (e.g., Beyer et al. 2010).

Second, we contribute to the literature studying whether firms communicate earnings information through dividends. Surveys and press releases suggest that managers view dividends as communicating earnings information (Brav et al. 2005; Kaplan and Perez-Cavazos 2021), but literature reviews conclude that dividends contain little or no information about future earnings (e.g., Allen and Michaely 2003; Kalay and Lemmon 2008; DeAngelo et al. 2009; Farre-Mensa et al. 2014). We contribute to this literature by reversing the standard event study methodology that attempts to predict unexpected earnings from dividend changes and instead showing that the presence of dividends affects the supply and demand for earnings information. However, we find that there is substantial heterogeneity in the information content of dividends, which is a new and important contribution of our study. This observation is important to future research because it highlights the limitations of conventional theories of dividends (i.e., signaling and agency), which assume homogeneity but have difficulty explaining dividends in the entire cross-section of firms.

Finally, our empirical results differ in several ways from what we would expect if dividends only convey information about earnings persistence or earnings quality (e.g., Skinner and Soltes 2011; Caskey and Hanlon 2013; Michaely et al. 2021). Skinner and Soltes (2011) show that dividend payers have more persistent earnings levels, which unconditionally should lead to larger ERCs. Studies also argue that 
dividend payers' higher quality earnings reduce the rate at which investors discount earnings (e.g., Grullon et al. 2002; Michaely et al. 2021), which would also tend to increase ERCs for dividend payers. Contrary to these perspectives, we find that dividends communicate permanent earnings information, leading to less persistent earnings surprises and thus smaller ERCs. In addition to providing evidence that the earnings information in dividends substitutes for the earnings information revealed at the EA, our earnings and expectations management tests provide the first evidence that the lower investor attention to EAs for dividend payers also impacts firms' disclosure incentives.

\section{Literature review and hypothesis development}

Our central hypothesis is that dividends supply the market with information about the firm's permanent earnings (Fama and French 1998; Skinner and Soltes 2011) and thus affect how market participants update expectations in response to new earnings information and how much managers focus on earnings. If dividends provide an additional signal of permanent earnings, we expect that (i) investors in dividend paying firms will update their earnings expectations less in response to earnings news at the EA, and (ii) the incremental earnings information supplied by dividends will affect the supply and demand for earnings information elsewhere, leading managers to make different decisions about the presentation and management of earnings. These hypotheses lie at the intersection of the dividend literature and the literature on the role of accounting information in the valuation and stewardship of the firm, which we discuss in this section.

\subsection{Dividends and earnings as substitutes in valuation}

Over a firm's life, cash inflows must equal outflows, so, with perfect foresight, valuing the firm using earnings, cash flows, or payout (i.e., dividends and buybacks) yields identical valuations. An important stream of literature (e.g., Feltham and Ohlson 1995; Penman and Sougiannis 1997; Penman and Yehuda 2019) argues that dividends provide limited information for firm value because future earnings (or, equivalently, future cash flows under clean-surplus accounting) are relevant for valuing a non-liquidating going concern, while dividends reduce firm value dollar-fordollar upon payout. However, market participants do not have perfect foresight, so payout can provide information about earnings and vice-versa (e.g., DeAngelo et al. 1992; Aharony and Dotan 1994; Guay and Harford 2000; Skinner and Soltes 2011). The weight that investors allocate to dividends and earnings will thus be a function of the importance of each information signal.

In contrast to prior studies' argument that dividends contain limited earnings information (e.g., from attempts to predict future earnings changes using dividend changes), we note that dividends can provide information about the level of future earnings and inform the market about permanent changes in earnings levels (DeAngelo et al. 1992, 1996; Guay and Harford 2000; Skinner and Soltes 2011; Ham et al. 
2020). Thus, at each specific EA, investors in dividend paying firms have less need to update for that period's earnings news because they have an additional signal about permanent earnings. Other aspects of dividend policy, such as firms rarely cutting dividends and managers facing penalties for cutting the dividend (Lintner 1956; Brav et al. 2005; Wu 2018), provide an economic rationale for dividend permanence. Given the penalties for cutting the dividend, most managers will not declare dividends they cannot sustain with permanent future earnings.

If dividends supply permanent earnings information that becomes embedded in pre-EA earnings expectations, we expect that investors and analysts will update their expectations of future earnings less in response to earnings realizations for dividend payers. Further, if dividends provide permanent earnings information, it is likely that payers' EAs consist of more transitory earnings news. As a result, we predict that each unit of earnings surprise generates lower market reactions for dividend payers. Therefore, we state our first hypothesis as follows:

\section{H1: Earnings announcements for dividend payers have lower earnings response coefficients than comparable announcements for non-payers.}

Our prediction that dividends and earnings serve as substitute sources of information contrasts with the complementary association predicted by several other dividend theories. First, under the agency view, non-dividend payers waste a higher proportion of earnings than payers (e.g., Easterbrook 1984; Jensen 1986), so investors should care more about payers' reported earnings because earnings that are supported by dividends are more credible (e.g., Kallapur 1994; Caskey and Hanlon 2013). ${ }^{5}$ Second, under the view that firms pay dividends to secure a lower discount rate (Grullon et al. 2002; Skinner and Soltes 2011; Michaely et al. 2021), the lower discount rate should lead to larger reactions to earnings surprises. Third, under the dividend catering view (Allen et al. 2000), dividend payers' investors are more sophisticated and demand more information overall.

\subsection{Dividends and earnings as substitutes in stewardship}

Prior literature shows that stakeholders monitor managers' performance relative to earnings benchmarks. Managers are judged relative to the analyst consensus forecast, and firms that miss this target suffer penalties in the form of reduced market value and human capital (Matsunaga and Park 2001; Skinner and Sloan 2002). To avoid these penalties, firms manage reported earnings, as well as the market's earnings expectations. Consistent with this, the portion of firms just beating earnings benchmarks substantially exceeds the fraction that just miss them (Burgstahler and Dichev 1997; Degeorge et al. 1999). Managing earnings to achieve benchmarks

\footnotetext{
${ }^{5}$ Prior research exploits cross-country or time-series variation in regulatory quality to show that dividends provide additional information supporting earnings in regimes with weak institutions (e.g., Sivakumar and Waymire 1993; Hail et al. 2014; Ellahie and Kaplan 2021). Our study differs from this work in that we examine the role of dividends within a strong regulatory environment.
} 
entails costs (Stein 1989; Bhojraj et al. 2009). If dividends provide information about permanent earnings, we expect that investors will fixate less on earnings (e.g., H1). In this case, managers of dividend paying firms will respond to this lack of fixation by delivering fewer earnings reports that just meet or beat analysts' earnings forecasts relative to non-dividend paying firms. ${ }^{6}$ Therefore, we state our second hypothesis as follows:

H2: Dividend payers are less (more) likely to just meet or beat (miss) earnings targets than non-payers.

\section{Sample selection and descriptive statistics}

We obtain our firm-level data from Compustat, CRSP, Thomson Reuters, and I/B/ E/S. The sample includes firms on the CRSP/Compustat Merged file between 1988 and 2017 with available quarterly EA dates, institutional ownership data, actual earnings, and consensus analyst earnings forecasts, as well as total assets and market capitalization greater than $\$ 10$ million. We further limit the sample to non-financial and non-utility firms; firms trading on the NYSE, NYSE MKT (formerly AMEX), or Nasdaq exchanges; and ordinary common US shares. We impose these restrictions, which are standard in the dividend literature, because regulations by industries, exchanges, and foreign countries can affect dividend payout, and we want to study firms operating under homogenous regulations. Finally, we require the control variables that we use across all of our tests, leaving a maximum sample of 224,765 firm-quarter (63,776 firm-year) observations for 7,513 firms. Our regression models generally include fewer observations than this because we also require the dependent variable and additional control variables relevant to each separate test. Table 1 presents the sample selection process.

\subsection{Descriptive statistics}

Table 2, Panel A presents descriptive statistics for dividend paying and non-paying firms separately. Variables are defined in Appendix Table 13. We find significant differences across all control variables in our analyses, highlighting the differences between dividend payers and non-payers. Consistent with the maturity hypothesis, payers are older (LogAge) and have more retained earnings $(R E)$ than non-payers (DeAngelo et al. 2006; Denis and Osobov 2008). They are also larger (LogMVE), but have weaker investment opportunities as measured by a higher book-to-market ratio (BTM), consistent with capital structure theory (Myers and Majluf 1984;

\footnotetext{
6 Several recent studies also examine how the firm's information environment affects firms' disclosure and earnings management choices (e.g., Abramova et al. 2020; Cho et al. 2020; Sul 2020). Our study extends this literature by comprehensively examining the role of dividends in the firm's information environment and is particularly important given prior views that dividends provide little information or serve as complements to earnings.
} 


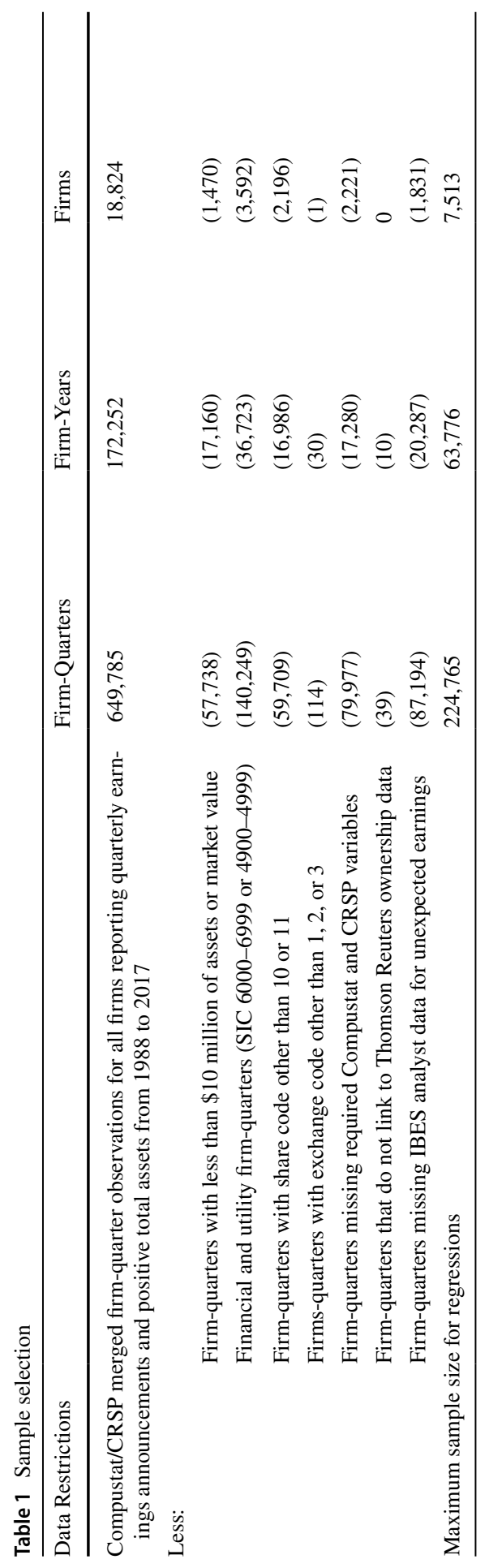




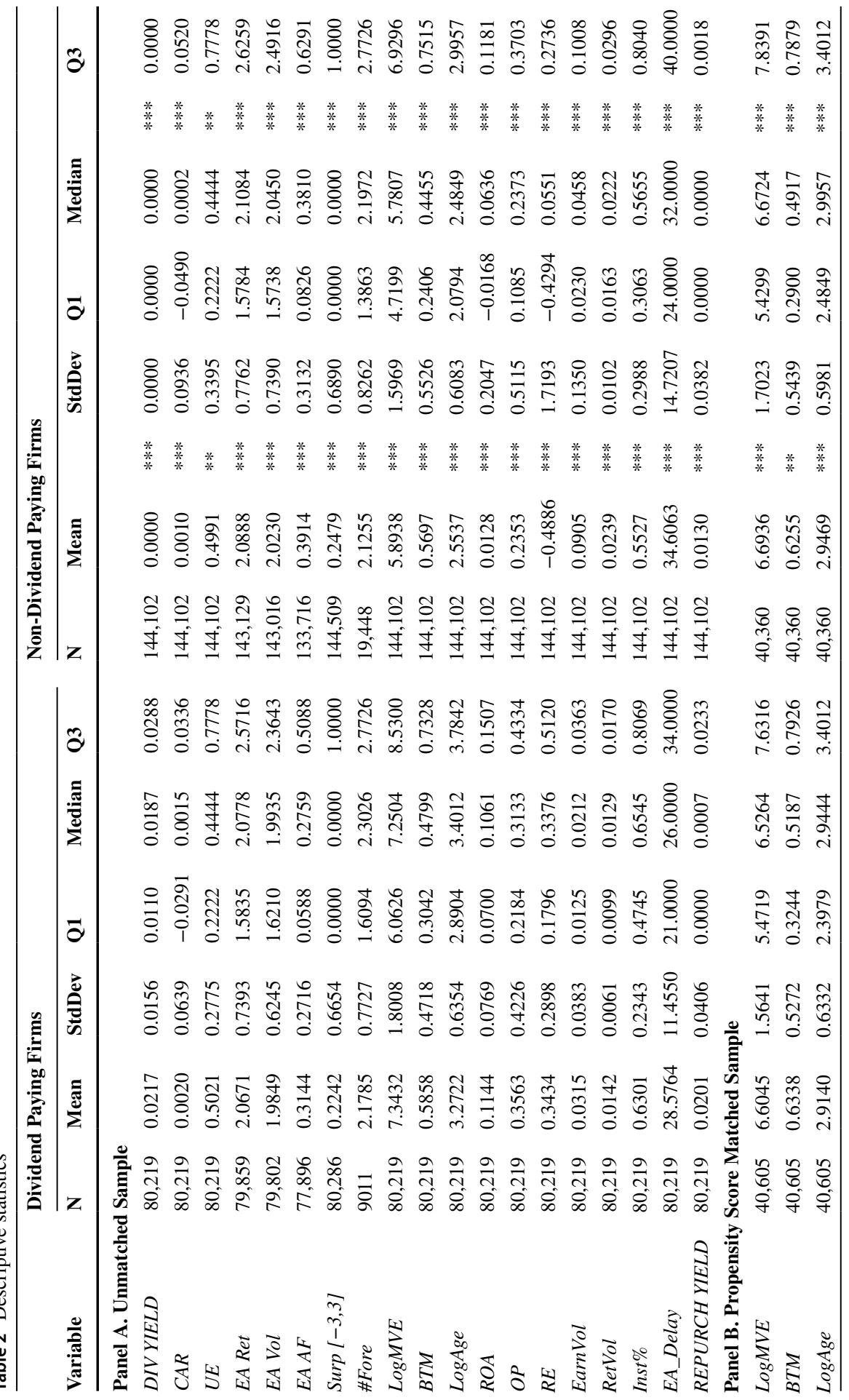




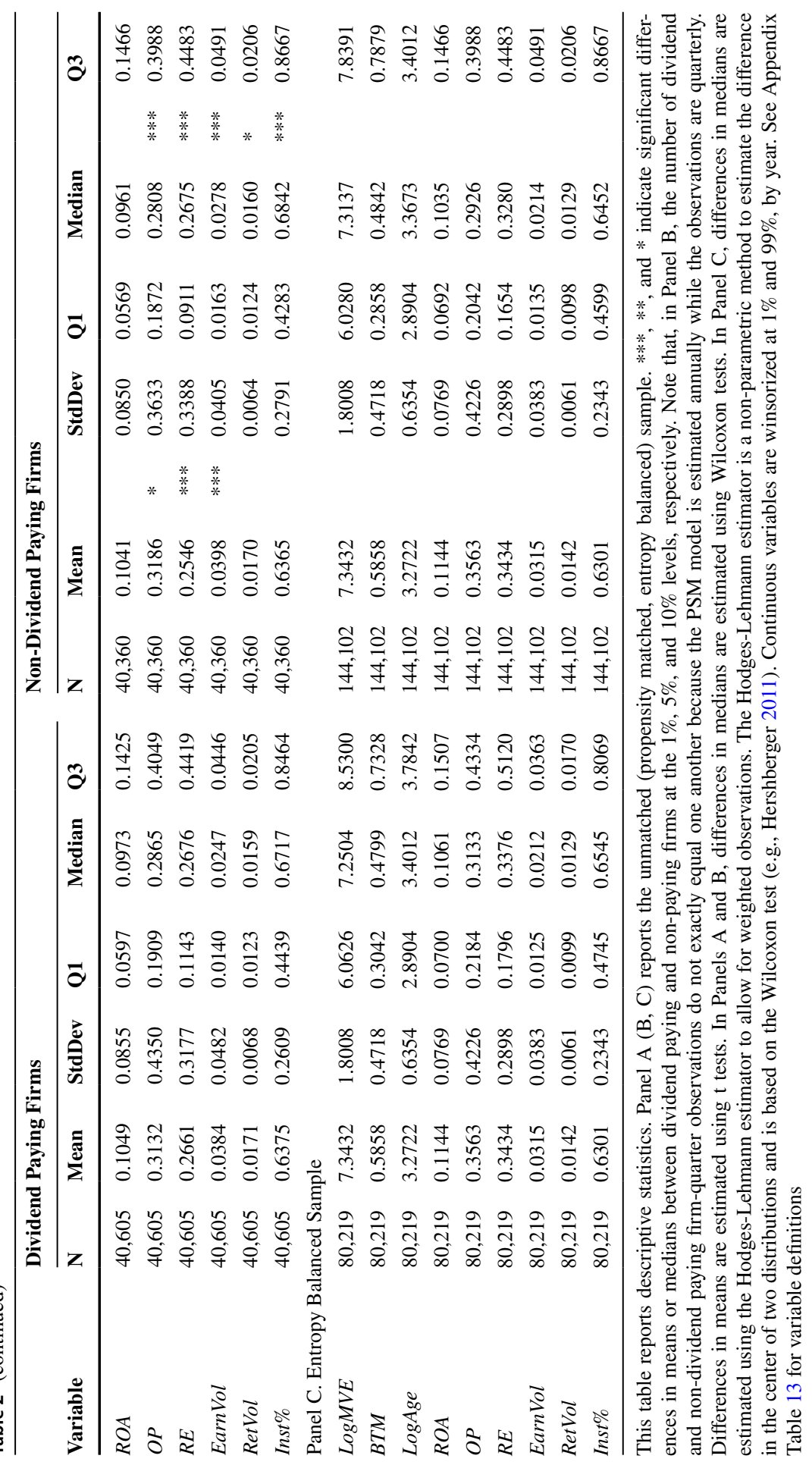


Bolton et al. 2011). Payers are more profitable (ROA, OP) and have lower earnings volatility (EarnVol), consistent with payers having permanent earnings they can use to fund payout (Skinner and Soltes 2011). Payers have lower return volatility (RetVol), consistent with cash flow uncertainty affecting the volatility of returns (Chay and Suh 2009). Finally, payers also have greater institutional ownership (Inst\%), consistent with dividends helping fund managers satisfy the prudent man rule (Del Guercio 1996; Grinstein and Michaely 2005).

Our empirical goal is to examine changes in the information environment that are associated with the decision to pay a dividend (H1), holding constant firm characteristics observable to investors. The substantial differences across firms in our descriptive statistics highlight the difficulty of this identification challenge, which we address using three empirical approaches. First, we use OLS regressions following the advice of Angrist and Pischke (2009, pp. 69-70), who note that including control variables in multivariate regression is generally sufficient to address differences in observable characteristics across firms. In addition to a full set of controls that prior studies have identified as determinants of the decision to pay a dividend, we include industry by year fixed effects so that our regression results compare firms that pay a dividend to firms that do not, controlling for time varying shocks that affect all firms in the same industry.

Second, we perform propensity score matching (PSM) based on a firm's propensity to pay dividends, which addresses potential issues related to non-linearities in control variables or a lack of common support (i.e., overlap) between dividend payers and non-payers (Shipman et al. 2017). For each dividend paying firm, we identify and match a non-paying firm with a similar propensity to pay. We estimate our propensity score model by regressing a firm's decision to pay a dividend on our main control variables (LogMVE, BTM, LogAge, ROA, OP, RE, EarnVol, RetVol, and $I n s t \%)$, as well as on industry and year fixed effects. We use a one-to-one match, without replacement, with common support, and with a caliper distance of 0.03 .

Third, we acknowledge that PSM is subject to limitations, including imperfect or random matches and deletion of both treatment (payer) and control (non-payer) firms that fail to match (e.g., DeFond et al. 2017). ${ }^{7}$ Entropy balancing uses an iterative process to re-weight observations in the control sample to match the observations in the treatment sample. Thus, in the entropy balanced sample, the first three moments (mean, variance, skewness) of the control variables detailed above should be nearly identical for payers versus non-payers. Effectively, non-dividend paying firms with characteristics similar to dividend payers receive more weight in our estimations, relative to non-payers with dissimilar characteristics. Entropy balancing discards zero or very few observations, which increases power relative to PSM and avoids limiting the control sample to one (randomly) matched observation. Both PSM and entropy balancing address potential functional form misspecification in

\footnotetext{
7 To address some of these concerns, Hainmueller (2012) and Hainmueller and Yiqing (2013) developed the entropy balancing technique. Entropy balancing is an "equal percent bias reducing" matching method, so, unlike PSM, it ensures that covariate imbalance improves after matching. See McMullin and Schonberger (2020) for a comprehensive discussion of entropy balancing.
} 
our models related to differences between dividend paying and non-paying firms (e.g., Roberts and Whited 2013; Shipman et al. 2017).

Table 2, Panel B (C) presents the descriptive statistics for the main control variables in the PSM (entropy balanced) sample. We find that covariate balance improves in the PSM sample relative to our unmatched descriptive statistics, but several statistically significant differences remain. However, these remaining differences are generally economically small at both the mean and median, and several go in the opposite direction as compared to the unmatched univariate statistics. In the entropy balanced sample, there are no statistically significant differences, and the descriptive statistics across paying and non-paying firms are virtually identical. By ensuring that dividend paying and non-paying firms are relatively similar in the matched samples, we reduce concerns that our results are driven by observable differences between payers and non-payers.

Our variable of interest in many of our analyses is an indicator variable set equal to one if the firm paid a quarterly dividend in the year before we measure our outcome variables. ${ }^{8}$ We primarily measure dividend paying using an indicator variable for two reasons: (i) our matching techniques are calibrated to dichotomous variables, and (ii) few firms pay trivial dividends, so for most firms the decision to pay a dividend is a dichotomous choice to make a commitment to return capital to shareholders. In Fig. 1, we present a histogram depicting the proportion of dividend paying firms falling into each range of yield values, at increments of $0.5 \%$. The lower mass of firms at $0 \%-0.5 \%$ yields than of firms at $1 \%-4 \%$ yields is consistent with few firms choosing to pay a trivial dividend. Nonetheless, in Table 7 we use a continuous measure of dividends via yield and find results similar to those when using an indicator variable.

\section{Valuation results-Informativeness of earnings announcements (H1)}

In this section, we reverse the standard event study methodology that attempts to predict unexpected earnings from dividends (e.g., Benartzi et al. 1997; Ham et al. 2020) and instead examine how the presence of a dividend affects the response to EAs. We propose that dividends provide market participants with an additional signal about permanent earnings, so we expect that market participants place less weight on earnings as an information source and thus react less at the EA (e.g., less response per unit of earnings surprise).

\footnotetext{
${ }^{8}$ Other dividend frequencies, such as annual, semi-annual or monthly, are very uncommon for the US non-financial firms in our sample. The second most common form of dividend during our sample period is the special dividend. Firms paid 35 times more in quarterly dividends than special dividends over our sample period, and most of the special dividends are paid by firms with regular quarterly dividends.
} 


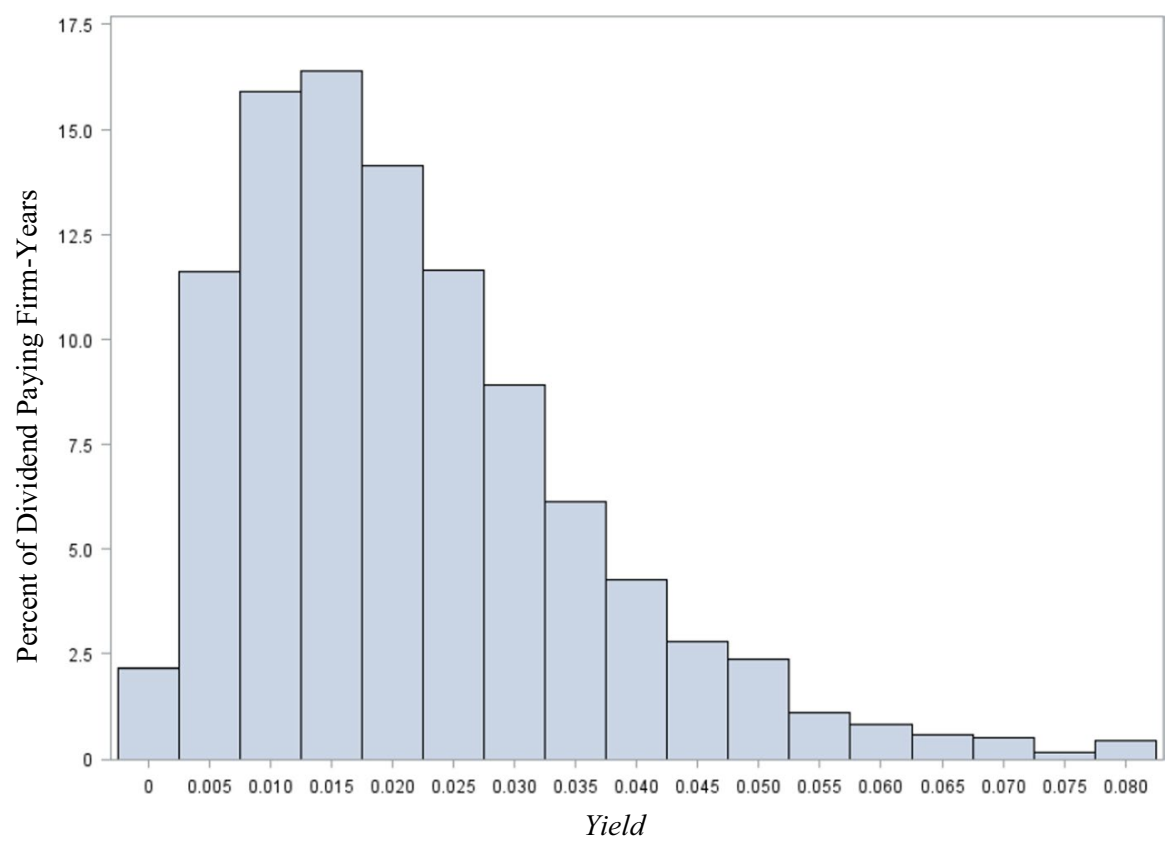

Fig. 1 Histogram of Yield. This figure presents a histogram of the distribution of Yield for the dividend paying firm-years in our full sample (21,707 firm-years), with bin widths of $0.5 \%$. For purposes of this figure, yields above $8 \%$ are set to $8 \%$. Yields are based on the last quarterly dividend announced during the year

\subsection{Dividends and their effect on earnings response coefficients}

Our first set of tests examines how paying a dividend affects the market reaction to the earnings surprise. If dividend payers have more information about permanent earnings in pre-EA earnings expectations, a higher (lower) proportion of the earnings surprise will likely be transitory (permanent) earnings news. Because transitory earnings news has less impact on announcement returns, H1 predicts lower ERCs for payers relative to non-payers (e.g., Easton and Zmijewski 1989; Ali and Zarowin 1992). We measure the dividend indicator and our main control variables in the year before we observe the market reaction and the earnings surprise. We use the following model to examine the relation between dividends and ERCs:

$$
\begin{aligned}
C A R_{i, q} & =\beta_{0}+\beta_{1} U E_{i, q}+\beta_{2} D_{I V}+\beta_{i, t} U E_{i, q} * D I V_{i, t} \\
& +\gamma_{k} C_{\text {CNTROLS }}+\mu_{k} U E_{i, q} * C O N T R O L S_{i, t} \\
& +\phi_{k} \text { YEAR } * U E_{i, q}+\omega_{k} Y E A R * I N D \_F E_{i, t}+\varepsilon
\end{aligned}
$$

where $i$ represents the firm, $t$ represents the most recent year prior to the quarterly EA date, and $q$ represents the current quarter (in year $t+1$ ). $C A R$ represents the market-adjusted signed abnormal return in the three-day trading window centered on the EA. DIV is an indicator variable set equal to one for dividend paying firms. We 
Table 3 Dividends and earnings response coefficients

\begin{tabular}{llll}
\hline & $(1)$ & $(2)$ & $(3)$ \\
& $C A R$ & $C A R$ & $C A R$ \\
\hline IIV & $0.0033 * * *$ & $0.0044 * * *$ & $0.0041^{* * *}$ \\
& $(3.175)$ & $(3.529)$ & $(3.416)$ \\
& $0.0708 * * *$ & $0.0744 * * *$ & $0.0826 * * *$ \\
$\boldsymbol{U E} * \boldsymbol{D I V}$ & $(10.730)$ & $(6.698)$ & $\mathbf{( 7 . 9 9 0 )}$ \\
& $\mathbf{- 0 . 0 0 8 1 * * *}$ & $\mathbf{- 0 . 0 0 9 3 * * *}$ & $\mathbf{- 0 . 0 0 9 3} * *$ \\
Industry * Year FE & $\mathbf{( - 4 . 4 0 6 )}$ & $\mathbf{( - 4 . 1 6 5 )}$ & $\mathbf{( - 4 . 1 9 4 )}$ \\
Controls & Yes & Yes & Yes \\
Controls * $U E$ & Yes & Yes & Yes \\
Year $* U E$ & Yes & Yes & Yes \\
Sample & Yes & Yes & Yes \\
Observations & Unmatched & Propensity & Entropy \\
Adjusted $\mathrm{R}^{2}$ & 224,321 & 80,965 & 224,321 \\
\hline
\end{tabular}

This table reports OLS regression results. The dependent variable is abnormal signed returns at the earnings announcement (CAR). Controls include LogMVE, BTM, LogAge, ROA, OP, RE, EarnVol, RetVol, Inst\%, and EA_Delay. Robust standard errors are clustered by firm. T-statistics are reported in parentheses. $* * *, * *$, and $*$ denote statistical significance at the $1 \%, 5 \%$, and $10 \%$ levels for two-tailed tests, respectively. Sample selection procedures are reported in Table 1. Variable definitions are reported in Appendix Table 13. The bolded variable names and coefficients are the key variables of interest

compute unexpected earnings $(U E)$ as the difference between reported earnings and the most recent median estimate on the I/B/E/S consensus file, scaled by share price at the beginning of the quarter. We then decile rank $U E$ and scale it to range from zero to one. If markets react less to earnings surprises for dividend paying firms, we will observe a negative coefficient on the interaction $U E^{*} D I V$.

We include several control variables that are likely to be correlated both with firms' decisions to pay dividends and with the information in firms' EAs. We include both the main effect of these controls and their interaction with $U E$. Specifically, we control for firm size (LogMVE), book-to-market (BTM), age (LogAge), return on assets $(R O A)$, operating profitability $(O P)$, retained earnings scaled by assets $(R E)$, earnings volatility (EarnVol), return volatility (RetVol), and institutional ownership (INST\%). These nine control variables represent our main control variables and are included in all of our subsequent models and used in our matching procedures. Because a longer delay could reduce the reaction to the EA (e.g., deHaan et al. 2015; Noh et al. 2021), we control for the time lag between the quarterly fiscal period end and the EA (EA_Delay) along with its interaction with $U E$. We include year by industry (two-digit SIC) fixed effects to account for common variation in EA responses within an industry over time. We also include year indicators interacted with $U E$ to account for time-series variation in ERCs (e.g., Gipper et al. 2020). Appendix Table 13 provides full variable definitions. 
Table 3 reports the results from estimating Eq. (1). In column (1), we use the unmatched sample and find that market reactions to earnings are significantly attenuated for dividend paying firms $(t=-4.4) .{ }^{9}$ To gauge the economic magnitude of the difference in the reaction to earnings, in untabulated analyses we estimate Eq. (1) after removing all year by $U E$ interactions (i.e., the reported $U E$ coefficient represents the baseline in a single year) and find an overall $U E$ coefficient of 0.072 , so our coefficient estimate for $D I V^{*} U E$ indicates that dividend payers have a $11.1 \%$ smaller reaction to earnings surprises than non-payers (i.e., $-0.008 / 0.072=11.1 \%$ ). In columns (2) and (3), we present the results using PSM and entropy balancing. The results remain statistically significant and indicate similar economic magnitudes: a $15.8 \%(13.4 \%)$ reduction in the response to earnings for payers using PSM (entropy balancing). Overall, we show that dividend paying firms have smaller reactions to unexpected earnings and that observable differences between payers and non-payers do not seem to drive the result.

\subsection{Dividend payers and the persistence of earnings surprises}

The notion that dividends supply permanent earnings information to the market predicts that payers' earnings surprises have a larger transitory component than nonpayers' surprises because the portion of permanent earnings information conveyed by the dividend is impounded into price before the EA (whereas for non-payers this information would more likely be impounded at the EA). We test this argument by examining whether earnings surprises have less information about future earnings for payers relative to non-payers. Specifically, we estimate Eq. (1), replacing the dependent variable $(C A R)$ with one-year-ahead earnings scaled by price $\left(\operatorname{Earn}_{t+1}\right)$. If our Table 3 results occur because of less persistent surprises for payers, we expect a negative coefficient on the interaction $U E^{*} D I V$.

In Table 4, column (1), we find a significantly negative coefficient on our interaction of interest $\left(U E^{*} D I V\right)$. In columns (2) and (3), we report similar results in our PSM and entropy balanced samples. In columns (4)-(6) we find similar results after including control variables for non-linearities in $U E$ (e.g., Fama and French 2000). ${ }^{10}$ Taken together with the prior literature, our results are consistent with (i) dividend payers responding to permanent earnings changes by changing dividends (i.e., DeAngelo et al. 1992; Guay and Harford 2000), and (ii) analysts and investors responding to dividend changes by revising their earnings expectations (Ham et al. 2020) so that pre-EA expectations reflect the permanent earnings information

\footnotetext{
9 Sivakumar and Waymire (1993) find that dividend paying firms have a higher market reaction to earnings over the period of 1905 to 1910 , before the NYSE required annual financial reporting. In their unique unregulated setting, the agency cost view of dividends (i.e., dividends signal that earnings are less likely to be wasted) may dominate the information substitution role that we document.

${ }^{10}$ In untabulated analyses we examine the persistence of earnings for dividend paying firms and verify that in our sample, consistent with the prior literature, dividend paying firms have greater earnings persistence in OLS regressions but equal earnings persistence as non-payers in entropy balanced regressions (DeAngelo et al. 1992; Skinner and Soltes 2011).
} 
Table 4 Dividends and earnings surprise persistence

\begin{tabular}{|c|c|c|c|c|c|c|}
\hline & $\begin{array}{l}\text { (1) } \\
\text { Earn }_{t+1}\end{array}$ & $\begin{array}{l}\text { (2) } \\
\text { Earn }_{t+1}\end{array}$ & $\begin{array}{l}\text { (3) } \\
\text { Earn }_{t+1}\end{array}$ & $\begin{array}{l}\text { (4) } \\
\text { Earn }_{t+1}\end{array}$ & $\begin{array}{l}\text { (5) } \\
\text { Earn }_{t+1}\end{array}$ & $\begin{array}{l}\text { (6) } \\
\text { Earn }_{t+1}\end{array}$ \\
\hline$D I V$ & $\begin{array}{l}0.0047 * * \\
(2.290)\end{array}$ & $\begin{array}{l}0.0062^{* * *} \\
(2.797)\end{array}$ & $\begin{array}{l}0.0048^{* *} \\
(2.535)\end{array}$ & $\begin{array}{l}0.0038 * * \\
(2.079)\end{array}$ & $\begin{array}{l}0.0066^{* * * *} \\
(3.245)\end{array}$ & $\begin{array}{l}0.0049 * * * \\
(2.875)\end{array}$ \\
\hline$U E$ & $\begin{array}{l}0.0305^{* *} \\
(2.281)\end{array}$ & $\begin{array}{l}0.0372 * \\
(1.914)\end{array}$ & $\begin{array}{l}0.0337 * * \\
(2.155)\end{array}$ & $\begin{array}{l}0.0284 * * \\
(2.062)\end{array}$ & $\begin{array}{l}0.0257 \\
(1.255)\end{array}$ & $\begin{array}{l}0.0250 \\
(1.542)\end{array}$ \\
\hline$U E * D I V$ & $\begin{array}{l}-0.0072 * * * \\
(-2.595)\end{array}$ & $\begin{array}{l}-0.0072 * * \\
(-2.326)\end{array}$ & $\begin{array}{l}-0.0077 * * * \\
(-3.072)\end{array}$ & $\begin{array}{l}-0.0054 * * \\
(-2.068)\end{array}$ & $\begin{array}{l}-0.0079 * * * \\
(-2.679)\end{array}$ & $\begin{array}{l}-0.0077 * * * \\
(-3.165)\end{array}$ \\
\hline Industry * Year FE & Yes & Yes & Yes & Yes & Yes & Yes \\
\hline Controls & Yes & Yes & Yes & Yes & Yes & Yes \\
\hline Controls * $U E$ & Yes & Yes & Yes & Yes & Yes & Yes \\
\hline Year * $U E$ & Yes & Yes & Yes & Yes & Yes & Yes \\
\hline $\begin{array}{l}\text { UE additional } \\
\text { controls }\end{array}$ & No & No & No & Yes & Yes & Yes \\
\hline Sample & Unmatched & Propensity & Entropy & Unmatched & Propensity & Entropy \\
\hline Observations & 177,266 & 65,826 & 177,266 & 177,266 & 65,826 & 177,266 \\
\hline Adjusted $\mathrm{R}^{2}$ & 0.371 & 0.254 & 0.241 & 0.400 & 0.283 & 0.274 \\
\hline
\end{tabular}

This table reports OLS regression results. The dependent variable is earnings for the subsequent year scaled by price $\left(E_{a r n}{ }_{t+1}\right)$. Controls include LogMVE, BTM, LogAge, ROA, OP, RE, EarnVol, RetVol, Inst \%, and EA_Delay. The additional UE controls include UE decile fixed effects, the earnings surprise scaled by price, the square of the earnings surprise scaled by price, an indicator set to one if the earnings surprise is negative, and the earnings surprise scaled by price multiplied by the negative surprise indicator. Robust standard errors are clustered by firm. T-statistics are reported in parentheses. ***, **, and * denote statistical significance at the $1 \%, 5 \%$, and $10 \%$ levels for two-tailed tests, respectively. Sample selection procedures are reported in Table 1. Variable definitions are reported in Appendix Table 13. The bolded variable names and coefficients are the key variables of interest

in dividends. Because pre-EA expectations reflect more permanent earnings news, dividend payers' EAs generate lower ERCs and the surprises have weaker implications for future earnings. ${ }^{11}$

\subsection{Variation in the timing of dividends relative to earnings}

If a firm provides earnings information and declares a dividend shortly thereafter, that dividend likely will not provide substantial new information about earnings. However, as the dividend declaration moves further away from the prior EA, it is likely to convey new information to the market that management has learned during the quarter or to reassure the market of the viability of the dividend as a signal of permanent earnings. Thus, within the sample of dividend payers, we expect that dividends

\footnotetext{
11 In untabulated analyses, we find no evidence that the smaller reaction to earnings surprises for dividend paying firms arises because of underreaction to earnings news (which would result in higher postEA drift) (Bernard and Thomas 1990). Specifically, we replace our dependent variable (i.e., announcement returns) with returns over the 60 trading days following the EA and re-estimate columns (1)-(3) of Table 3. In all specifications we find that $U E^{*} D I V$ loads with a statistically insignificant coefficient.
} 
Table 5 Dividends and ERCs: dividend timing

(1)

\begin{tabular}{lll}
\hline Dependent variable: & $C A R$ & $C A R$ at $D I V_{q+1}$ \\
NEWS variable: & $U E$ & $D I V C H G$ \\
TIMING variable: & $\# D A Y S\left(D I V_{q}-E A_{q-1}\right)$ & $\# D A Y S\left(D I V_{q+1}-E A_{q}\right)$ \\
NEWS & $0.081^{* * *}$ & 0.015 \\
& $(5.742)$ & $(1.107)$ \\
TIMING & $0.009^{* * *}$ & $-0.004 * *$ \\
& $(2.866)$ & $(-2.376)$ \\
NEWS * TIMING & $\mathbf{- 0 . 0 1 8 * * *}$ & $\mathbf{0 . 0 0 6}$ \\
& $(-\mathbf{3 . 1 4 3})$ & $\mathbf{( 1 . 8 7 2})$ \\
Industry * Year FE & Yes & Yes \\
Controls & Yes & Yes \\
Controls * NEWS & Yes & Yes \\
Year* NEWS & Yes & Yes \\
Sample & Payers Only & Payers Only \\
Observations & 49,945 & 49,882 \\
Adjusted $\mathrm{R}^{2}$ & 0.136 & 0.009
\end{tabular}

This table reports OLS regression results. The dependent variable is abnormal signed returns at the earnings announcement $(C A R)$ in column (1) and abnormal signed returns at the dividend announcement (CAR at DIV) in column (2). Controls include LogMVE, BTM, LogAge, ROA, OP, RE, EarnVol, RetVol, Inst\%, and EA_Delay. Robust standard errors are clustered by firm. T-statistics are reported in parentheses. $* * *, * *$, and $*$ denote statistical significance at the $1 \%, 5 \%$, and $10 \%$ levels for two-tailed tests, respectively. Sample selection procedures are reported in Table 1. Variable definitions are reported in Appendix Table 13. The bolded variable names and coefficients are the key variables of interest

are more likely to serve as a substitute for the information in EAs as the dividend gets further away from the prior EA. To test this hypothesis, we introduce the variable \#DAYS $\left(D I V_{q}-E A_{q-1}\right)$, which is a measure of the time between the prior quarter EA date and the dividend declaration date scaled to range from zero to one. We then estimate Eq. (1) replacing DIV with \#DAYS $\left(D I V_{q}-E A_{q-1}\right)$ and restricting the sample to dividend payers that do not bundle their dividend with the EA. ${ }^{12}$ We present results in Table 5. We find a significantly negative coefficient on $U E^{* \# D A Y S}\left(D I V_{q}-E A_{q-1}\right)$, consistent with dividends exhibiting a stronger substitution effect when announced longer after the prior EA. Because this analysis is within payers only, it also rules out concerns that differences between payers and non-payers drive our main results.

Our predictions also imply the converse: when the firm announces a dividend shortly after the EA, the dividend declaration will convey less information to investors than a dividend declaration more removed in event time from the prior

\footnotetext{
${ }^{12}$ For bundled dividend announcements, we cannot disentangle the market reaction to earnings from that for dividends, so we omit these firms from this analysis.
} 
EA. Thus, using the same sample as above, we examine whether the next dividend announcement becomes more informative as it moves away from the current EA. We modify the prior equation to replace $U E$ with $D I V C H G$, which is equal to the decile rank of the percentage change in the dividend scaled to range between zero and one, similar to the calculation of $U E$. The timing variable is calculated as the number of days from the current EA to the subsequent dividend announcement, scaled to be between zero and one (\#DAYS $\left.\left(D I V_{q+1}-E A_{q}\right)\right)$. The dependent variable $C A R$ at $D I V_{q+1}$ is also calculated in the same manner as before, but is the three-day return centered on the dividend announcement rather than the EA. Consistent with substitution, we find a significantly positive interaction term on DIVCHG*\#DAYS $\left(D I V_{q+1}-E A_{q}\right)$, indicating that the market reaction to the dividend announcement increases as the announcement moves away from the EA.

\subsection{Heterogeneity in the degree to which dividends substitute for earnings information}

Not all dividends proxy for permanent earnings. For example, firms with substantial cash holdings do not need future earnings to sustain the dividend, so managers have more freedom to set the dividend regardless of earnings. Some firms pay a trivial dividend, so the commitment to sustain the dividend provides little, if any, earnings information to investors. Finally, some dividends become unsustainable and are not expected to continue; therefore, they no longer provide permanent earnings information. In this section, we examine these three sources of heterogeneity in the extent to which dividends substitute for information in earnings. In these contexts, we expect that dividends convey less information about permanent earnings.

\subsubsection{Variation in the likelihood of cutting the dividend}

We hypothesize that firms that are likely to cut their dividend convey less permanent earnings information through the dividend because they are unable to commit to sustaining the dividend permanently. To test this hypothesis, we estimate a propensity score model of the firm cutting or omitting the dividend in year $t+1$ as a function of time $t$ firm characteristics. We supplement our base set of controls with separate indicators for negative earnings and returns in year $t$ as well as the most recent 12-month return, to reflect the increased probability of a firm cutting the dividend when firm news has been negative (e.g., Benartzi et al. 1997). Our propensity score model includes no dividend information, which allows us to estimate a propensity to cut the dividend for all firms in our sample (including firms that do not pay a dividend). We estimate the propensity score model (untabulated) and find a ROC of 0.684 , suggesting we can explain an acceptable fraction of the propensity to cut the dividend (Hosmer et al. 2013), which is consistent with other models in the literature (e.g., Ayers et al. 2015; Beardsley et al. 2020). We decile rank the 
Table 6 Dividends and ERCs: cross-sectional analyses

\begin{tabular}{|c|c|c|}
\hline & $\begin{array}{l}(1) \\
C A R\end{array}$ & $\begin{array}{l}(2) \\
C A R\end{array}$ \\
\hline$D I V$ & $\begin{array}{l}0.0077 \text { *** } \\
(4.973)\end{array}$ & $\begin{array}{l}0.0046^{* * * *} \\
(3.763)\end{array}$ \\
\hline$U E$ & $\begin{array}{l}0.0732 * * * \\
(10.738)\end{array}$ & $\begin{array}{l}0.0748 * * * \\
(11.154)\end{array}$ \\
\hline$U E * D I V$ & $\begin{array}{l}-0.0181 \text { *** } \\
(-6.546)\end{array}$ & $\begin{array}{l}-0.0131 * * * \\
(-5.999)\end{array}$ \\
\hline$U E * D I V * P R(C U T)$ & $\begin{array}{l}0.0199 * * * \\
(4.063)\end{array}$ & \\
\hline$D I V * P R(C U T)$ & $\begin{array}{l}-0.0081 \text { *** } \\
(-2.886)\end{array}$ & \\
\hline$U E * P R(C U T)$ & $\begin{array}{l}-0.0226^{* * *} \\
(-6.302)\end{array}$ & \\
\hline$P R(C U T)$ & $\begin{array}{l}0.0108 * * * \\
(4.915)\end{array}$ & \\
\hline$U E * D I V * C A S H$ & & $\begin{array}{l}0.0416 * * * \\
(3.775)\end{array}$ \\
\hline$D I V * C A S H$ & & $\begin{array}{l}-0.0134 * * \\
(-2.212)\end{array}$ \\
\hline$U E * C A S H$ & & $\begin{array}{l}-0.0114 * * * \\
(-2.703)\end{array}$ \\
\hline $\mathrm{CASH}$ & & $\begin{array}{l}-0.0019 \\
(-0.753)\end{array}$ \\
\hline Industry * Year FE & Yes & Yes \\
\hline Controls & Yes & Yes \\
\hline Controls * $U E$ & Yes & Yes \\
\hline Year * UE & Yes & Yes \\
\hline Sample & Unmatched & Unmatched \\
\hline Observations & 220,873 & 224,292 \\
\hline Adjusted $\mathrm{R}^{2}$ & 0.104 & 0.103 \\
\hline
\end{tabular}

This table reports OLS regression results. The dependent variable is abnormal signed returns at the earnings announcement (CAR). Controls include LogMVE, BTM, LogAge, ROA, OP, RE, EarnVol, RetVol, Inst \%, and EA_Delay. Robust standard errors are clustered by firm. T-statistics are reported in parentheses. $* * *, * *$, and $*$ denote statistical significance at the $1 \%, 5 \%$, and $10 \%$ levels for two-tailed tests, respectively. Sample selection procedures are reported in Table 1. Variable definitions are reported in Appendix Table 13. The bolded variable names and coefficients are the key variables of interest

propensity to cut the dividend and scale these ranks so that they range from zero to one $(P R(C U T))$.

We then test whether a higher propensity to cut the dividend attenuates the lower ERCs for dividend payers relative to non-payers by modifying Eq. (1) to include $P R(C U T)$ and fully interacting it with $D I V$ and $U E$. 


$$
\begin{aligned}
C A R_{i, q} & =\beta_{0}+\beta_{1} U E_{i, q}+\beta_{2} D I V_{i, t}+\beta_{3} U E_{i, q} * D I V_{i, t}+\beta_{4} P R(C U T) \\
& +\beta_{5} D I V_{i, t} * P R(C U T)+\beta_{6} U E_{i, q} * P R(C U T)+\beta_{7} U E_{i, q} * D I V_{i, t} * P R(C U T) \\
& +\gamma_{k} \operatorname{CONTROLS}_{i, t}+\mu_{k} U E_{i, q} * \text { CONTROLS } \\
i, t & +\phi_{k} Y E A R * U E_{i, q}+\omega_{k} Y E A R * I N D \_F E_{i, t}+\varepsilon
\end{aligned}
$$

Column (1) of Table 6 reports the results from estimating Eq. (2). Our variable of interest is the triple interaction $U E^{*} D I V^{*} P R(C U T)$. We find a significantly positive coefficient, consistent with our hypothesis that the dividend serves as a weaker substitute for earnings when it is more likely to be cut. The sum of $U E^{*} D I V^{*} P R(C U T)$ and $U E^{*} D I V$ is positive $(p<0.01)$, so for the firms in the top decile of likelihood to cut the dividend, the dividend does not convey information about permanent earnings to the market. In fact, a high likelihood of cutting the dividend appears to make earnings more important, perhaps because they are informative about future dividend cuts.

\subsubsection{Variation in available cash to fund the dividend}

For firms with large cash balances, dividends do not necessarily provide a signal of permanent earnings, because the firm can sustain the dividend through existing cash rather than future earnings (e.g., Kaplan and Perez-Cavazos 2021). Similar to the propensity to cut the dividend in the above section, non-dividend payers also have cash holdings, so we can estimate a difference-in-difference design estimating the incremental effect of cash holdings on the information content of the EA for payers relative to non-payers.

Specifically, we test whether higher levels of cash attenuate the lower ERCs for dividend payers relative to non-payers. We modify Eq. (2), replacing $P R(C U T)$ with $C A S H$ (cash and cash equivalents scaled by assets). Column (2) of Table 6 reports the results. Consistent with the hypothesis that larger cash reserves reduce the substitution between dividends and earnings, we find a significantly positive coefficient on $U E^{*} D I V^{*} C A S H$. The point estimate for payers in the 90th percentile of $C A S H$ ( $25.9 \%$ of assets) equals 0.011 $(0.0416 * 25.9 \%)$, largely offsetting the baseline substitution effect for $U E^{*} D I V(-0.013)$.

\subsubsection{Variation in the yield and effects of repurchases}

If investors view dividends as a measure of permanent earnings, the portion of firm value the dividend explains will be proportional to the yield (similar to a perpetuity). When the dividend explains more of firm value, dividends (EAs) will convey more (less) information about firm value, which leads us to predict greater substitution for higher yielding firms. ${ }^{13}$ Examining yield also allows us to contrast our predictions for dividend payments with those for repurchases. From a capital structure perspective, dividends and repurchases are equivalent because each form of payout removes cash from the firm and gives it to shareholders (Faulkender and Wang 2006; Kaplan and Perez-Cavazos 2021). However, from an informational perspective, buybacks tend to correspond to transitory

\footnotetext{
13 An extreme example of a low yielding firm is Nvidia, who as of February 12th 2021 had a trailing twelve month dividend yield of $0.1 \%$, and had not changed the dividend in two years. Even if investors expect that the dividend represents permanent earnings, the market still needs to see substantial earnings beyond the dividend to explain the valuation, so EAs will be more important for low yielding firms like Nvidia.
} 
earnings, while dividends correspond to persistent earnings (Guay and Harford 2000; Sun et al. 2020; Wang et al. 2021). Thus, repurchases serve as a falsification test in our analyses, to ensure that the results are driven by the permanent earnings information in dividends rather than transitory earnings that lead to repurchases.

To test whether dividends substitute for information to a greater extent when the yield is higher, we modify Eq. (1), replacing the dividend indicator (DIV) with the dividend yield (DIV YIELD). A negative interaction on $U E^{*} D I V$ YIELD indicates that substitution increases in yield. We also include repurchase yield (REPURCH YIELD) and interact REPURCH YIELD with UE. The hypothesis that dividends substitute for EA information more than repurchases predicts that the coefficient on $U E^{*} D I V$ YIELD is less than the coefficient on $U E^{*} R E P U R C H$ YIELD. We estimate the following model.

$$
\begin{aligned}
& C A R_{i, q}=\beta_{0}+\beta_{1} U E_{i, q}+\beta_{2} D I V Y I_{E L D} D_{i, t}+\beta_{3} U E_{i, q} * D I V Y I E L D_{i, t} \\
& +\beta_{4} \text { REPURCH YIELD } D_{i, t}+\beta_{5} U E_{i, q} * \text { REPURCH YIELD }{ }_{i, t} \\
& +\gamma_{k} \text { CONTROLS }_{i, t}+\mu_{k} U_{i, q} * \text { CONTROLS }_{i, t} \\
& +\phi_{k} Y E A R * U E_{i, q}+\omega_{k} Y E A R * I N D \_F E_{i, t}+\varepsilon
\end{aligned}
$$

Column (1) of Table 7 reports the results from estimating Eq. (3). We find $U E^{*} D I V$ YIELD loads with a highly significant negative coefficient $(t=-6.36)$, consistent with dividend substitution increasing in yield. We find $U E^{*} R E P U R C H$ YIELD loads with an insignificant negative coefficient, which is also significantly less negative than the coefficient on $U E^{*} D I V$ YIELD and over ten times smaller in magnitude.

In Fig. 2, we plot the substitution between payout at different yields, for both repurchases and dividends, to provide additional evidence that the degree of substitution varies with yield. Specifically, we modify Eq. (3) by including separate indicators for each $1 \%$ interval of dividend or repurchase yield (i.e., $0 \%-1 \%$ range, $1 \%-2 \%$ range, $2 \%-3 \%$ range, $3 \%-4 \%$ range, and above $4 \%$ ), and interact each of these indicators with $U E$. Figure 2 shows that dividend substitution increases monotonically with yield, consistent with the dividend providing more permanent earnings information at higher yields. Specifically, the coefficient on the $1 \%-2 \%$ yield group interaction falls just short of conventional levels of statistical significance $(p=0.111)$, but the coefficient magnitude is more than double the insignificant coefficient on the $0 \%-1 \%$ yield group interaction. The $2 \%-3 \%$ yield group has a significant interaction, and its magnitude is significantly larger than that of the $1 \%-2 \%$ yield group $(p=0.059)$. The $3 \%-4 \%$ yield group has a significant interaction, and the magnitude is significantly larger than that of the $2 \%-3 \%$ yield group $(p=0.009)$. The above $4 \%$ group has a significant coefficient, slightly larger in magnitude than that of the 3\%-4\% group $(p=0.742) .{ }^{14}$ Examining repurchase yields, only one of the repurchase yield interactions is significantly different from zero, and this effect is significantly smaller than for the equivalent dividend yield level.

\footnotetext{
${ }^{14}$ In untabulated analyses, we show these high yielding firms are significantly more likely to cut the dividend, so the absence of an economically significant increase in substitution with yields at very high levels of yield is consistent with our results in section 4.4.1.
} 
Table 7 Dividends and ERCs: dividends versus repurchases

\begin{tabular}{|c|c|c|c|}
\hline & $\begin{array}{l}\text { (1) } \\
C A R\end{array}$ & $\begin{array}{l}(2) \\
C A R\end{array}$ & $\begin{array}{l}(3) \\
C A R\end{array}$ \\
\hline$U E$ & $\begin{array}{l}0.0717 * * * \\
(10.860)\end{array}$ & $\begin{array}{l}0.0710 * * * \\
(10.726)\end{array}$ & $\begin{array}{l}0.0783 * * * \\
(4.745)\end{array}$ \\
\hline DIV YIELD & $\begin{array}{l}0.1239 * * * \\
(4.291)\end{array}$ & & $\begin{array}{l}0.1552 * * * \\
(2.897)\end{array}$ \\
\hline REPURCH YIELD & $\begin{array}{l}0.0132 \\
(1.243)\end{array}$ & & $\begin{array}{l}-0.0115 \\
(-0.612)\end{array}$ \\
\hline$U E * D I V Y I E L D$ & $\begin{array}{l}-0.3289 * * * \\
(-6.360)\end{array}$ & & $\begin{array}{l}-0.4276 * * * \\
(-4.535)\end{array}$ \\
\hline UE * REPURCH YIELD & $\begin{array}{l}-0.0244 \\
(-1.370)\end{array}$ & & $\begin{array}{l}-0.0070 \\
(-0.215)\end{array}$ \\
\hline DIV ONLY YIELD & & $\begin{array}{l}0.0808^{* *} \\
(2.496)\end{array}$ & \\
\hline$D I V \&$ REPURCH YIELD & & $\begin{array}{l}0.0326 * * \\
(2.213)\end{array}$ & \\
\hline REPURCH ONLY YIELD & & $\begin{array}{l}0.0185 \\
(1.451)\end{array}$ & \\
\hline$U E * D I V O N L Y Y I E L D$ & & $\begin{array}{l}-0.1854 * * * \\
(-3.175)\end{array}$ & \\
\hline$U E * D I V \&$ \&EPURCH YIELD & & $\begin{array}{l}-0.1038 * * * \\
(-4.065)\end{array}$ & \\
\hline UE * REPURCH ONLY YIELD & & $\begin{array}{l}-0.0114 \\
(-0.535)\end{array}$ & \\
\hline Industry * Year FE & Yes & Yes & Yes \\
\hline Controls & Yes & Yes & Yes \\
\hline Controls * $U E$ & Yes & Yes & Yes \\
\hline Year * UE & Yes & Yes & Yes \\
\hline Sample & Unmatched & Unmatched & $\begin{array}{l}D I V>0 \& \\
\quad R E P U R C H>0\end{array}$ \\
\hline Observations & 224,321 & 224,321 & 44,788 \\
\hline Adjusted $\mathrm{R}^{2}$ & 0.103 & 0.103 & 0.126 \\
\hline
\end{tabular}

This table reports OLS regression results. The dependent variable is abnormal signed returns at the earnings announcement (CAR). Controls include LogMVE, BTM, LogAge, ROA, OP, RE, EarnVol, RetVol, Inst\%, and EA_Delay. Robust standard errors are clustered by firm. T-statistics are reported in parentheses. $* * *, * *$, and $*$ denote statistical significance at the $1 \%, 5 \%$, and $10 \%$ levels for two-tailed tests, respectively. Sample selection procedures are reported in Table 1. Variable definitions are reported in Appendix Table 13. The bolded variable names and coefficients are the key variables of interest

Next, we partition firms that pay out into three subsamples (e.g., Skinner 2008): dividend and repurchase (20.0\% of sample), dividend only ( $15.8 \%$ of sample), and repurchase only (19.8\% of sample). We classify firms based on payout in the prior year. We note that there is considerable disparity in terms of the 


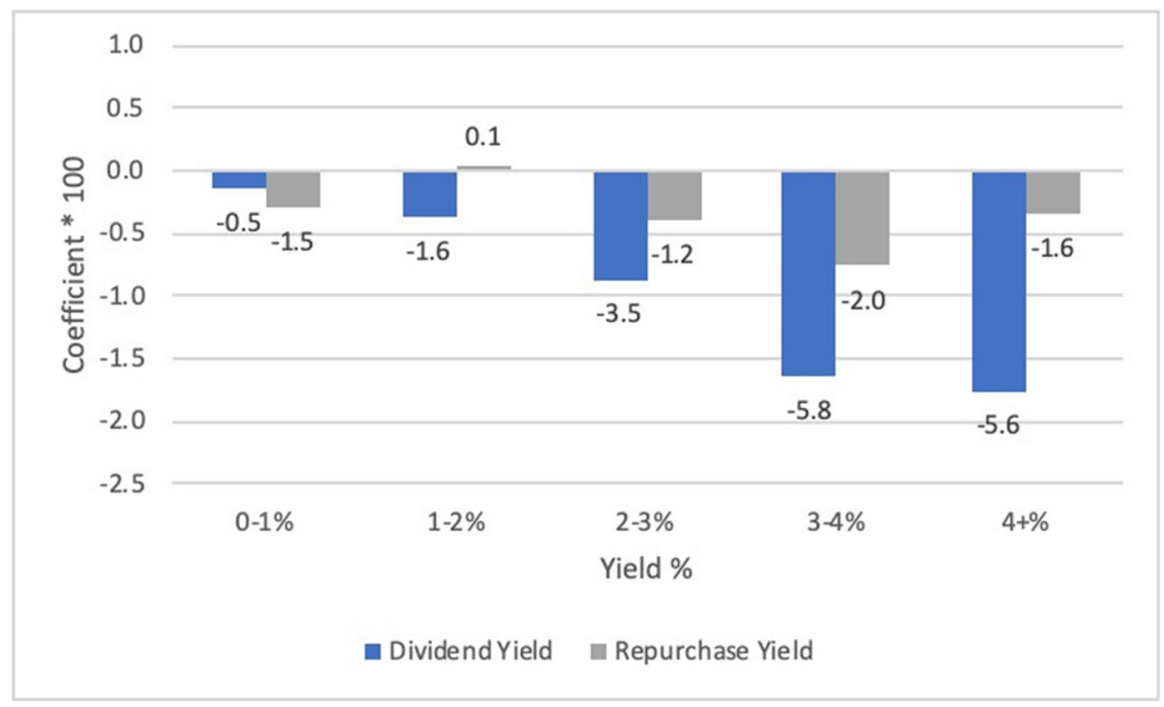

Fig. 2 Dividend yield versus repurchase yield-ERCs. This figure presents coefficient estimates from estimating a modified specification of column (1) in Table 7. We decompose both dividend yield and repurchase yield into five groups $(0 \%-1 \%, 1 \%-2 \%, 2 \%-3 \%, 3 \%-4 \%$, and $4+\%)$ and include indicator variables for each group as well as interactions with $U E$ in the model. The bars plot the estimated coefficient (the indicator for each level *UE). T-statistics (clustered by firm) are displayed above or below the corresponding bar

annualized yield across the groups. Average total payout is largest for dividend and repurchase firms at $5.7 \%$ (DIV \& REPURCH YIELD), more than double the $2.2 \%$ yield for dividend only firms (DIV ONLY YIELD) and slightly higher than the $4.2 \%$ yield in the repurchase only subsample (REPURCH ONLY YIELD). Among firms paying dividends and repurchasing shares, dividend yield $(2.1 \%)$ is lower than repurchase yield $(3.6 \%)$.

In column (2) of Table 7, we compare the substitution effect for categories of firms by replacing DIV YIELD and REPURCH YIELD with the yields from our three groups of firms (e.g., DIV \& REPURCH YIELD, DIV ONLY YIELD, and REPURCH $O N L Y$ YIELD) and interact each with $U E$. We show that dividend only yield has a marginally more negative effect on the market reaction to earnings than yield from dividend and repurchasing firms $(p=0.146)$. Although the difference in coefficients is not statistically significant, the coefficient on UE*DIV ONLY YIELD is $79 \%$ larger than the coefficient on $U E^{*} D I V \&$ REPURCH YIELD. The coefficients for both groups of payers are significantly more negative than both zero and the coefficient for the repurchase only group $(p<0.01)$, which is insignificantly different from zero.

To ensure that dividend yield drives the results in the dividend and repurchasing group in column (2), we next decompose the significant coefficient for $U E^{*} D I V$ \& REPURCH YIELD into a component attributable to dividends and a component attributable to repurchases. Specifically, we restrict the sample to firms that both pay a dividend and repurchase, then include both UE*DIV YIELD and UE*REPURCH YIELD in the model. In column (3), we continue to find $U E^{*} D I V$ YIELD loads with 
a statistically significant coefficient that is over ten times the insignificant coefficient on $U E^{*} R E P U R C H$ YIELD. This confirms that in this group of repurchasing dividend payers, the payout information substituting for the information in earnings comes from the dividend, not the repurchase.

\subsection{Dividends and the attention to earnings}

In this section, we examine whether the lower ERCs for dividend payers translate into lower investor attention at the EA. Because dividends substitute for earnings information in firm valuation, we expect that attention constrained investors will allocate less attention to the EA, translating into lower overall responses at the EA. We use three measures to capture EA attention. First we use trading volume, which measures investors' decisions to trade at the EA and is likely correlated with the decision to process a firm's EA disclosures (e.g., Beaver 1968; Bamber 1986; Roychowdhury and Sletten 2012). The second measure of EA attention is return volatility, because models of information acquisition show that return volatility provides an incentive for investors to acquire and process information (e.g., Kim and Verrecchia 1991). The third measure of EA attention is analyst forecasts. Analysts have incentives to forecast in response to new information, so the timing of their forecasts proxies for the overall amount of EA information. We use the following regression model to test for a shift in attention:

$$
\text { EA_Measure } e_{i, q}=\beta_{0}+\beta_{1} D I V_{i, t}+\gamma_{k} \text { CONTROLS }_{i, t}+\mu_{k} \text { UE Decile } F E_{i, q}+\omega_{k} Y E A R * I N D \_F E_{i, t}+\varepsilon
$$

where $i$ represents the firm, $q$ represents the current quarter, and $t$ represents the most recent year prior to the quarterly EA date. EA_Measure represents one of three measures of EA responses: EA_Vol, EA_Ret, and EA_AF. Following Roychowdhury and Sletten (2012), EA_Vol measures the information content in the EA as the sum of trading volume over the three-day EA window $[-1,1]$ relative to the sum of total trading volume for the quarter, excluding the EA window. We measure EA_Ret similarly, using the absolute value of daily market-adjusted returns in place of volume. Finally, $E A \_A F$ is also measured similarly, except we compare the number of analysts' forecasts issued in the EA window to the number issued over the entire quarter. We use the entire quarter to scale the $E A \_A F$ measure, rather than the non-EA window, because unlike volume and returns there can be zero forecasts in the nonEA window. Adjusting EA volume, returns, and forecasts for total firm news within the quarter allows our measure to capture variation in the firm-specific percentage of information at the EA relative to the rest of the firm's quarter, rather than simply capturing cross-sectional differences in firms' overall volume or volatility. Under $\mathrm{H} 1$, we predict a negative coefficient for dividend paying firms $(D I V)$. We control for LogMVE, BTM, LogAge, ROA, OP, RE, EarnVol, RetVol, INST\%, and EA_Delay as in Eq. (1). We also control for the magnitude of unexpected earnings (UE) by including $U E$ decile fixed effects, and include year by industry (two-digit SIC) fixed effects to account for common variation in EA responses within an industry over time. 
Table 8 Dividends and earnings announcement attention

Panel A: Trading Volume

$\begin{array}{llll} & (1) & (2) & (3) \\ \boldsymbol{D I V} & E A \_V o l & E A \_V o l & E A \_V o l \\ & \mathbf{- 0 . 0 9 0 * * *} & \mathbf{- 0 . 0 6 8} * * * & \mathbf{- 0 . 0 6 0 * * *} \\ \text { Industry * Year FE } & \mathbf{( - 1 3 . 2 6 3 )} & \mathbf{( - 8 . 7 7 1 )} & \mathbf{( - 6 . 8 7 2 )} \\ \text { Controls } & \text { Yes } & \text { Yes } & \text { Yes } \\ \text { UE decile FE } & \text { Yes } & \text { Yes } & \text { Yes } \\ \text { Sample } & \text { Yes } & \text { Yes } & \text { Yes } \\ \text { Observations } & \text { Unmatched } & \text { Propensity } & \text { Entropy } \\ \text { Adjusted R } & 222,818 & 80,529 & 222,818\end{array}$

Panel B: Absolute Returns

\begin{tabular}{|c|c|c|c|}
\hline & (1) & (2) & (3) \\
\hline & EA_Ret & EA_Ret & EA_Ret \\
\hline \multirow[t]{2}{*}{$D I V$} & $-0.070 * * *$ & $-0.068 * * *$ & $-0.059 * * *$ \\
\hline & $(-10.535)$ & $(-8.736)$ & $(-5.948)$ \\
\hline Industry * Year FE & Yes & Yes & Yes \\
\hline Controls & Yes & Yes & Yes \\
\hline$U E$ decile FE & Yes & Yes & Yes \\
\hline Sample & Unmatched & Propensity & Entropy \\
\hline Observations & 222,818 & 80,529 & 222,818 \\
\hline Adjusted $\mathrm{R}^{2}$ & 0.140 & 0.152 & 0.171 \\
\hline \multicolumn{4}{|c|}{ Panel C: Number of Analyst Forecasts } \\
\hline & (1) & $(2)$ & (3) \\
\hline & $E A \_A F$ & $E A \_A F$ & $E A \_A F$ \\
\hline \multirow[t]{2}{*}{$D I V$} & $-0.030 * * *$ & $-0.026 * * *$ & $-0.015 * * *$ \\
\hline & $(-7.707)$ & $(-5.898)$ & $(-3.399)$ \\
\hline Industry * Year FE & Yes & Yes & Yes \\
\hline Controls & Yes & Yes & Yes \\
\hline$U E$ decile FE & Yes & Yes & Yes \\
\hline Sample & Unmatched & Propensity & Entropy \\
\hline Observations & 211,786 & 77,751 & 211,786 \\
\hline Adjusted $\mathrm{R}^{2}$ & 0.462 & 0.479 & 0.514 \\
\hline
\end{tabular}

This table reports OLS regression results. In Panel A $(\mathrm{B}, \mathrm{C})$ the dependent variable is trading volume (EA_Vol) (absolute returns [EA_Ret], the number of analyst forecasts $\left[E A \_A F\right]$ ) at the earnings announcement. Controls include LogMVE, BTM, LogAge, ROA, OP, RE, EarnVol, RetVol, Inst\%, and EA_Delay. Robust standard errors are clustered by firm. T-statistics are reported in parentheses. ***, **, and $*$ denote statistical significance at the $1 \%, 5 \%$, and $10 \%$ levels for two-tailed tests, respectively. Sample selection procedures are reported in Table 1. Variable definitions are reported in Appendix Table 13. The bolded variable names and coefficients are the key variables of interest

Table 8, Panel A presents our results using trading volume, our primary measure of EA attention. Column (1) reports results from estimating OLS regressions in the unmatched sample. We find payers generate $4.4 \%(-0.090 / 2.023)$ less volume at 
the EA compared to non-payers. In columns (2) and (3), we use PSM and entropy balancing, respectively, to control for differences between payers and non-payers. We continue to find significantly lower EA volume for dividend paying firms: $3.4 \%$ $(-0.068 / 2.023)$ in column (2), and 3.0\% (-0.060 / 2.023) in column (3). Panels B and $\mathrm{C}$ present similar results using returns and analysts' forecasts, respectively.

\section{Stewardship results $(\mathrm{H} 2)$}

Our initial tests show that capital market participants respond less to EAs for dividend payers. We next examine whether the decrease in investor focus on reported earnings leads managers to focus less on meeting or beating earnings expectations (H2). In addition to showing evidence related to the earnings discontinuity around analyst expectations - which survey and empirical research has shown firms incur costs to exceed (e.g., Graham et al. 2005; Bird et al. 2019)—we show that earnings and expectations management decrease, providing evidence on the mechanisms through which managers reduce their emphasis on meet or beat.

\subsection{The effect of dividend paying on meeting or beating}

Managers of firms whose unmanaged earnings would just miss expectations tend to manage earnings upward or expectations downward so that earnings just exceed the benchmark. However, because investors of dividend paying firms focus less on earnings, we expect these behaviors to be attenuated for managers of dividend payers. That is, because dividends draw investors' attention away from earnings for payers, we propose that managers expend fewer resources to just meet or beat earnings expectations. This should lead to a discontinuity around earnings expectations where payers are more (less) likely to report earnings just below (above) expectations relative to non-payers. We test this prediction using the following model:

$$
\operatorname{Surp}[X, Y]_{i, q}=\beta_{0}+\beta_{1} D I V_{i, t}+\gamma_{k} \operatorname{CONTROLS} S_{i, t}+\omega_{k} Y E A R * I N D \_F E_{i, t}+\varepsilon
$$

where Surp represents a series of indicator variables to capture earnings that fall just above or just below the median of the outstanding consensus forecast. We measure $D I V$ in the year prior to the quarter at which we measure Surp. This allows us to examine how financial reporting outcomes are correlated with prior payout choices, because research shows analysts incorporate payout into their expectations (e.g., Ham et al. 2020). CONTROLS include our nine main control variables, as well as the natural logarithm of the number of analysts following the firm (\#Analyst). We also include industry by year fixed effects. We obtain both actual earnings and forecasts from the I/B/E/S unadjusted file to avoid imprecision associated with rounding (Payne and Thomas 2003), and we split-adjust these values when necessary (Robinson and Glushkov 2006). We predict the coefficient on DIV will be below zero for earnings realizations just above the consensus (i.e., payers are less likely 


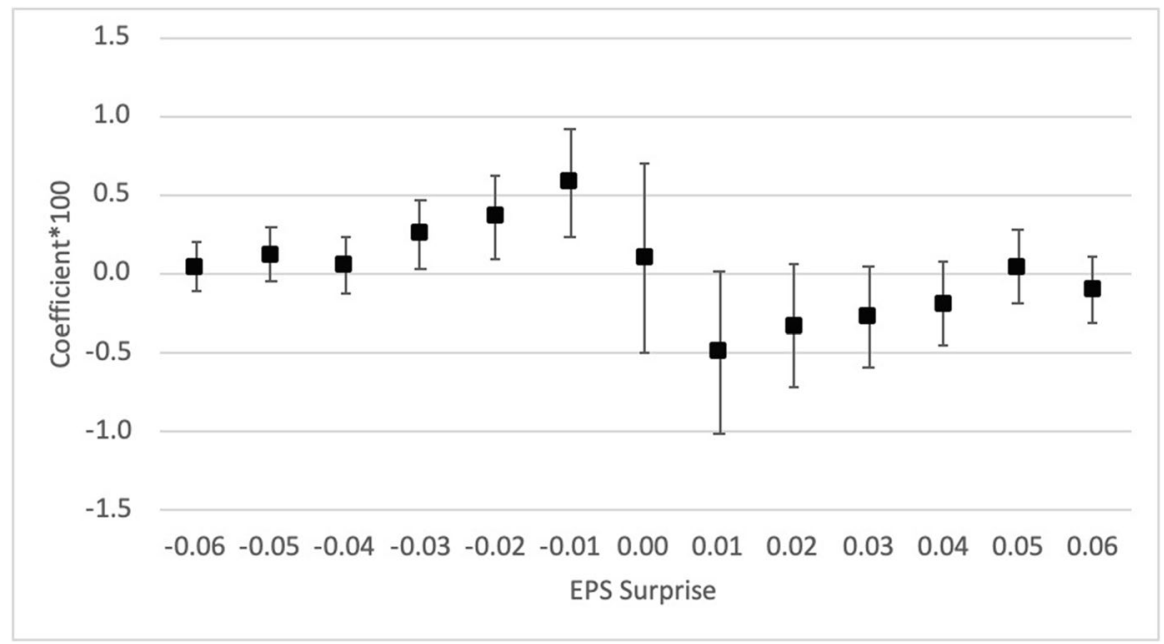

Fig. 3 Dividends and meeting or beating. This figure presents coefficient estimates and $95 \%$ confidence intervals from estimating a modified specification of column (1) in Table 9. The dependent variable is an indicator for each penny earnings per share surprise beginning with actual earnings six cents below the consensus and ending with actual earnings six cents above the consensus. We plot the coefficient estimates on the dividend indicator (DIV) from each of the 13 regressions

to just meet) and above zero for earnings realizations just below the consensus (i.e., payers are more likely to just miss), and that both coefficients will attenuate as we move away from the zero threshold (because incentives to manage earnings are most intense around zero).

We begin our analysis by plotting the impact of $D I V$ on meeting or beating around the consensus. Specifically, we estimate 13 regressions, one for each penny beginning with actual earnings six cents below the consensus through six cents above the consensus. For example, Surp [-1] is set to one if the forecast error falls in the range $[-0.01,0.00)$, Surp [0] is set to one if the forecast error is equal to zero, and Surp [1] is set to one if the forecast error falls in the range $(0.00,0.01]$. All other variables are as previously defined. This specification allows us to determine whether dividend paying firms are less (more) likely than non-dividend paying firms to report earnings that just meet or beat (miss) the analyst consensus.

In Fig. 3, we graph the coefficient on DIV, as well as the corresponding 95\% confidence interval, for the 13 specifications over the forecast error range $[-0.06,0.06]$. The results are stark: relative to non-payers, dividend paying firms are more likely to just miss the consensus forecast and less likely to just meet or beat it. As the forecast error moves away from zero in both directions, the coefficient on DIV moves towards, and becomes statistically indistinguishable from, zero. The significantly positive coefficient just below the consensus and the significantly negative coefficient just above the consensus are inconsistent with alternative explanations, such as the notion that dividend paying firms have different earnings dispersion. 
Table 9 Dividends and meeting or beating

\begin{tabular}{llll}
\hline & $(1)$ & $(2)$ & $(3)$ \\
& Surp $[-3,3]$ & Surp $[-3,3]$ & Surp $[-3,3]$ \\
\hline $\mathbf{D I V}$ & $\mathbf{- 0 . 0 2 2} * * *$ & $\mathbf{- 0 . 0 2 7} * * *$ & $\mathbf{- 0 . 0 1 8 * *}$ \\
& $\mathbf{( - 3 . 5 0 3 )}$ & $\mathbf{( - 3 . 8 3 6 )}$ & $\mathbf{( - 2 . 2 1 4 )}$ \\
Industry * Year FE & Yes & Yes & Yes \\
Controls & Yes & Yes & Yes \\
Sample & Unmatched & Propensity & Entropy \\
Observations & 224,765 & 76,158 & 224,675 \\
Adjusted R & 0.041 & 0.042 & 0.056 \\
\hline
\end{tabular}

This table reports OLS regression results. The dependent variable is set to negative (positive) one if the firm just misses (beats) the consensus forecast. Controls include LogMVE, BTM, LogAge, ROA, OP, RE, EarnVol, RetVol, Inst\%, and \#Analyst. Robust standard errors are clustered by firm. T-statistics are reported in parentheses. ***,**, and * denote statistical significance at the $1 \%, 5 \%$, and $10 \%$ levels for two-tailed tests, respectively. Sample selection procedures are reported in Table 1. Variable definitions are reported in Appendix Table 13. The bolded variable names and coefficients are the key variables of interest

Table 9 presents regression results after using our matching approaches to control

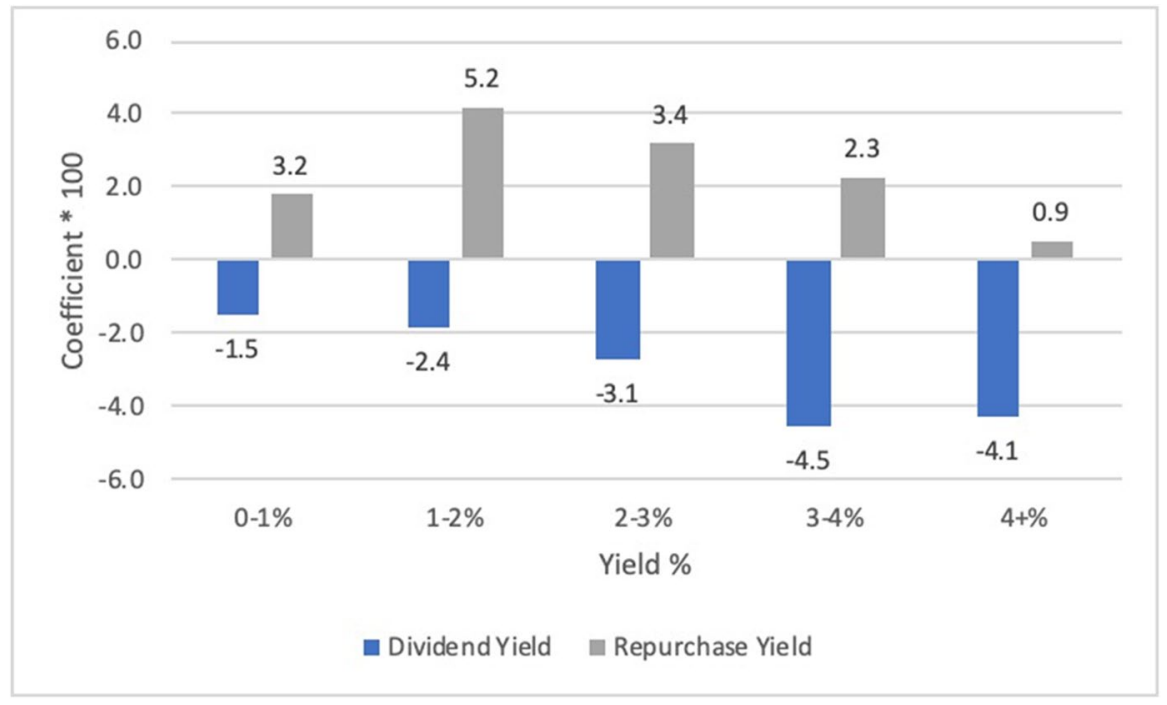

Fig. 4 Dividend yield versus repurchase yield-meeting or beating. This figure presents coefficient estimates from estimating a modified specification of column (1) in Table 9. We decompose both dividend yield and repurchase yield into five groups $(0 \%-1 \%, 1 \%-2 \%, 2 \%-3 \%, 3 \%-4 \%$, and $4+\%)$ and include indicator variables for each group in the model. The bars plot the estimated coefficient for each indicator, and $\mathrm{t}$-statistics (clustered by firm) are displayed above or below the corresponding bar

for observable differences across dividend payers and non-payers. For this analysis we define the dependent variable as $\operatorname{Surp}[-3,3]$, which equals negative one if the 
forecast error falls in the range $[-0.03,0.00)$, positive one if the forecast error falls in the range $[0.00,0.03]$, and zero otherwise. Column (1) reports the results using our baseline unmatched sample. The coefficient on DIV is negative and statistically significant. Columns (2) and (3) also report significantly negative coefficients using the PSM sample and the entropy balanced sample. In terms of economic magnitudes, our coefficient estimates of $1.8 \%-2.7 \%$ indicate a $7.3 \%-10.9 \%$ decline in just meeting or beating relative to just missing for dividend paying firms. ${ }^{15}$

In Fig. 4, we present results using indicator variables that group firms into dividend or repurchase yield ranges (i.e., $0 \%-1 \%$ range, $1 \%-2 \%$ range, $2 \%-3 \%, 3 \%-4 \%$, $4 \%$ and above). The results show that the likelihood of meeting or beating decreases with the dividend yield. Conversely, we find the opposite relation for repurchase yields - they are positively associated with meet or beat behavior (e.g., Hribar et al. 2006). Overall, we show dividend payers have less of a discontinuity around the consensus earnings forecast, supporting $\mathrm{H} 2$.

\subsection{Dividend paying and managing earnings to exceed thresholds}

We would like to interpret our meet or beat findings as indicating that dividend paying shifts (i.e., reduces) the benefits of managing earnings, so that dividend payers are less willing to incur the associated costs. In this section, we present evidence that lower earnings management contributes to dividend paying firms' lower propensity to just meet or beat. We note that prior evidence suggests that dividend payers are less likely than non-payers to engage in extreme forms of earnings management like fraud (Caskey and Hanlon 2013). Our evidence complements this research by examining the role of dividends in meet or beat, focusing on a broad set of earnings management techniques rather than only extreme cases.

If stakeholders of dividend paying firms place less weight on earnings, we expect that managers of dividend paying firms will be less willing to sacrifice long-term value to hit short-term earnings targets (Graham et al. 2005). Evidence of differential earnings management behavior would indicate that the meet or beat results suggest less myopic behavior for dividend paying firms, which represents a possible benefit of paying dividends. We thus examine whether dividend paying firms are less likely to manage earnings to meet or beat earnings expectations by estimating the following difference-in-differences model (Bhojraj et al. 2009):

$$
\begin{aligned}
\Delta E M_{i, q} & =\beta_{0}+\beta_{1} \operatorname{DIV}_{i, t}+\beta_{2} \operatorname{Surp}[-3,3]_{i, q}+\beta_{3} \operatorname{DIV}_{i, t} * \operatorname{Surp}[-3,3]_{i, q} \\
& +\gamma_{k} \text { CONTROLS }_{i, t}+\omega_{k} \text { YEAR } * I N D \_F E_{i, t}+\varepsilon
\end{aligned}
$$

Our dependent variable, $\triangle E M$, measures the change in one of several financial statement variables suggested in prior research as helping firms achieve their reporting objectives (research and development expense, revenues, or accounts receivable). The first

\footnotetext{
15 We compute these economic magnitudes by dividing the coefficient on $D I V$, our estimate of the difference between payers and non-payers, by the difference between the percentage of non-payers that just meet or beat and the percentage of non-payers that just miss $(24.8 \%)$.
} 
Table 10 Dividends and mechanisms for meeting or beating: earnings management

\begin{tabular}{|c|c|c|c|c|c|c|}
\hline & $\begin{array}{l}(1) \\
\Delta R \& D\end{array}$ & $\begin{array}{l}\text { (2) } \\
\Delta R e v\end{array}$ & $\begin{array}{l}(3) \\
\Delta A R\end{array}$ & $\begin{array}{l}\text { (4) } \\
\Delta R \& D\end{array}$ & $\begin{array}{l}\text { (5) } \\
\Delta R e v\end{array}$ & $\begin{array}{l}\text { (6) } \\
\Delta A R\end{array}$ \\
\hline DIV & $\begin{array}{l}-0.197 * * * \\
(-10.304)\end{array}$ & $\begin{array}{l}-0.930 \text { *** } \\
(-8.889)\end{array}$ & $\begin{array}{l}-0.587 * * * \\
(-8.703)\end{array}$ & $\begin{array}{l}-0.185^{* * *} \\
(-9.790)\end{array}$ & $\begin{array}{l}-1.063 * * * \\
(-10.096)\end{array}$ & $\begin{array}{l}-0.655 * * * \\
(-9.722)\end{array}$ \\
\hline Surp $[-3,3]$ & $\begin{array}{l}-0.074 * * * \\
(-6.721)\end{array}$ & $\begin{array}{l}0.767 * * * \\
(18.770)\end{array}$ & $\begin{array}{l}0.333 * * * \\
(11.078)\end{array}$ & & & \\
\hline SurpI $-3,3] * D I V$ & $\begin{array}{l}0.044 * * * \\
(3.385)\end{array}$ & $\begin{array}{l}-0.530 * * * \\
(-9.024)\end{array}$ & $\begin{array}{l}-0.281 * * * \\
(-6.752)\end{array}$ & & & \\
\hline Surp $[7,13]$ & & & & $\begin{array}{l}0.053 * * \\
(2.329)\end{array}$ & $\begin{array}{l}-0.141^{*} \\
(-1.647)\end{array}$ & $\begin{array}{l}-0.049 \\
(-0.863)\end{array}$ \\
\hline $\operatorname{Surp}[7,13] * D I V$ & & & & $\begin{array}{l}-0.062 * * \\
(-2.468)\end{array}$ & $\begin{array}{l}0.192 * \\
(1.738)\end{array}$ & $\begin{array}{l}0.092 \\
(1.258)\end{array}$ \\
\hline Industry * Year FE & Yes & Yes & Yes & Yes & Yes & Yes \\
\hline Controls & Yes & Yes & Yes & Yes & Yes & Yes \\
\hline Sample & Unmatched & Unmatched & Unmatched & Unmatched & Unmatched & Unmatched \\
\hline Observations & 114,159 & 223,171 & 220,311 & 114,159 & 223,171 & 220,311 \\
\hline Adjusted $\mathrm{R}^{2}$ & 0.048 & 0.149 & 0.121 & 0.047 & 0.146 & 0.120 \\
\hline
\end{tabular}

This table reports OLS regression results. The dependent variable is the change in $R \& D$ expenses $(\Delta R \& D)$, revenues $(\Delta R e v)$, or receivables $(\triangle A R)$. Controls include LogMVE, BTM, LogAge, ROA, OP, RE, EarnVol, RetVol, Inst\%, and \#Analyst. Robust standard errors are clustered by firm. T-statistics are reported in parentheses. $* * *, * *$, and * denote statistical significance at the $1 \%, 5 \%$, and $10 \%$ levels for two-tailed tests, respectively. Sample selection procedures are reported in Table 1. Variable definitions are reported in Appendix Table 13. The bolded variable names and coefficients are the key variables of interest

difference is whether the firm pays a dividend. The second difference is Surp [-3,3], which captures whether the firm exceeded or missed expectations. We expect that firms just above the threshold will be more likely to manage earnings to achieve the benchmark, whereas firms that miss the benchmark will be less likely to have managed earnings. Our variable of interest is $D I V * \operatorname{Surp}[-3,3]$, which captures the differential likelihood that dividend payers manage earnings. We expect that payers manage earnings less aggressively to achieve expectations, which would lead to a positive (negative) coefficient on $D I V * \operatorname{Surp}[-3,3]$ when $\Delta R \& D$ (either $\Delta R e v$ or $\Delta A R$ ) is the dependent variable.

We report the results in Table 10. In column (1), the dependent variable is the change in R\&D expense (e.g., Bhojraj et al. 2009). The coefficient on Surp [-3,3] is negative and statistically significant, consistent with the firms in our sample cutting R\&D expenses to meet or beat. The interaction with $D I V$ is positive and statistically significant, suggesting payers are less likely to cut $R \& D$ expense to reach the consensus earnings expectation. In columns (2) and (3), the dependent variables are the change in revenues and receivables; this is motivated by Stubben (2010), who shows that most earnings management relates to inflating revenues and receivables. As expected, the coefficient on Surp [-3,3] is positive and statistically significant in both columns, and the interaction with DIV is significantly negative in both columns. 
Table 11 Dividends and mechanisms for meeting or beating: non-GAAP disclosures and conference call earnings discussion

\begin{tabular}{|c|c|c|c|c|}
\hline & $\begin{array}{l}(1) \\
\text { NonGAAP }\end{array}$ & $\begin{array}{l}\text { (2) } \\
\text { \#EarnWords }\end{array}$ & $\begin{array}{l}\text { (3) } \\
\text { NonGAAP }\end{array}$ & $\begin{array}{l}\text { (4) } \\
\text { \#EarnWords }\end{array}$ \\
\hline$D I V$ & $\begin{array}{l}-0.054 * * * \\
(-3.911)\end{array}$ & $\begin{array}{l}0.035^{*} \\
(1.662)\end{array}$ & $\begin{array}{l}-0.060 * * * \\
(-4.409)\end{array}$ & $\begin{array}{l}0.024 \\
(1.120)\end{array}$ \\
\hline Surp $[-3,3]$ & $\begin{array}{l}0.024 * * * \\
(6.242)\end{array}$ & $\begin{array}{l}0.056^{* * *} \\
(9.658)\end{array}$ & & \\
\hline SurpI $[-3,3] * D I V$ & $\begin{array}{l}-0.029 * * * \\
(-3.940)\end{array}$ & $\begin{array}{l}-0.043 * * * \\
(-3.742)\end{array}$ & & \\
\hline Surp $[7,13]$ & & & $\begin{array}{l}-0.013 * * \\
(-2.150)\end{array}$ & $\begin{array}{l}-0.014 \\
(-1.544)\end{array}$ \\
\hline Surp $[7,13] * D I V$ & & & $\begin{array}{l}0.016 \\
(1.591)\end{array}$ & $\begin{array}{l}0.018 \\
(1.236)\end{array}$ \\
\hline Industry * Year FE & Yes & Yes & Yes & Yes \\
\hline Controls & Yes & Yes & Yes & Yes \\
\hline Sample & Unmatched & Unmatched & Unmatched & Unmatched \\
\hline Observations & 80,457 & 88,190 & 80,457 & 88,190 \\
\hline Adjusted $\mathrm{R}^{2}$ & 0.187 & 0.215 & 0.186 & 0.213 \\
\hline
\end{tabular}

This table reports OLS regression results. The dependent variable is an indicator for non-GAAP earnings disclosures (NonGAAP) or the number of earnings words on the conference call (\#EarnWords). Controls include LogMVE, BTM, LogAge, ROA, OP, RE, EarnVol, RetVol, Inst\%, and \#Analyst. Robust standard errors are clustered by firm. T-statistics are reported in parentheses. ***,**, and * denote statistical significance at the $1 \%, 5 \%$, and $10 \%$ levels for two-tailed tests, respectively. Sample selection procedures are reported in Table 1. Variable definitions are reported in Appendix Table 13. The bolded variable names and coefficients are the key variables of interest

In columns (4)-(6) we estimate analogous specifications to columns (1)-(3), but use a placebo threshold centered around a positive ten cent surprise instead of a zero cent surprise. If our results are a mechanical function of reported earnings, we would expect to see similar results around the placebo threshold, which managers do not care about, as around the zero threshold. For this analysis, the independent variable, Surp [7,13], equals negative one if the forecast error falls in the range $[0.07,0.10)$, one if the forecast error falls in the range [0.10,0.13], and zero otherwise. When we use R\&D and revenue as the variable of interest in columns (4) and (5), we find that $D I V^{*} \operatorname{Surp}[7,13]$ loads with significant coefficients that are opposite in sign to those in columns (1) and (2). In column (6), we find an insignificant coefficient using receivables to measure earnings management. Untabulated results are similar if we center around a ten cent loss-all three interactions load with the opposite sign of those in columns (1)-(3).

\subsection{Dividend paying and managers' focus on earnings}

Next, we evaluate managers' focus on earnings by examining managers' provision of a non-GAAP earnings figure (Bentley et al. 2018). Because there is substantial 
uncertainty as to the transitory line items that should be removed from GAAP earnings to create "street" earnings, I/B/E/S uses managerial input to determine street earnings (e.g., Doyle et al. 2013). Thus, managers can influence actual earnings through their interpretation of unusual line items in the current quarter's earnings (e.g., Bratten et al. 2020). To test whether non-GAAP earnings are more commonly used by non-payers to meet or beat, we modify Eq. (6) by replacing the dependent variable with an indicator variable if management reports a non-GAAP earnings figure for the concurrent quarter. We report results in Table 11. In column (1), we find a positive and significant coefficient on Surp [-3,3], suggesting the firms in our sample use non-GAAP earnings disclosures to assist in meeting or beating. The interaction with $D I V$ is significantly negative, suggesting dividend payers are less likely to use non-GAAP earnings disclosures to meet the consensus earnings expectation because of their lower focus on earnings. This result is also consistent with dividend payers facing less demand for non-GAAP earnings, which predominantly removes transitory line items from earnings, given the permanent earnings information provided by the dividend.

In column (2), the dependent variable is the number of times managers mention earnings during the prepared remarks portion of the firm's quarterly conference call. We expect managers will be more likely to discuss their earnings when they achieve the earnings benchmark, but that this tendency will be significantly attenuated for dividend payers because payers' managers focus less on earnings. Consistent with this expectation, the coefficient on Surp [-3,3] is positive and statistically significant, suggesting managers are more likely to highlight earnings when the firm just meets or beats, relative to when the firm misses the consensus forecast. The interaction with $D I V$ is significantly negative, suggesting the managers of dividend payers are less focused on highlighting earnings when the firm just meets or beats the consensus (or less reticent to discuss earnings when the firm just misses it).

As in Table 10, we also estimate columns (1) and (2) around a placebo earnings threshold, a ten cent surprise. The coefficients on Surp [7,13] in columns (3) and (4) are both of the opposite sign relative to the corresponding coefficients in columns (1) and (2), and only one is statistically significant. The interactions with DIV are also statistically insignificant.

\subsection{Dividend paying and forecasting}

Finally, we examine whether managers of dividend payers are less likely to provide an additional signal of earnings in the form of management guidance. Failing to provide a forecast of earnings can decrease the likelihood that firms meet or beat because analysts tend to over-weight management forecasts in their own estimates, allowing managers to use forecasts to create beatable expectations (e.g., Skinner 
Table 12 Dividends and management forecasts

\begin{tabular}{llll}
\hline & $(1)$ & $(2)$ & $(3)$ \\
& \#Fore & \#Fore & \#Fore \\
\hline DIV & $\mathbf{- 0 . 1 2 5 * * *}$ & $\mathbf{- 0 . 1 5 4 * * *}$ & $\mathbf{- 0 . 0 7 6 * * *}$ \\
& $\mathbf{( - 5 . 3 5 9 )}$ & $\mathbf{( - 6 . 0 0 1 )}$ & $\mathbf{( - 2 . 6 3 6 )}$ \\
Industry * Year FE & Yes & Yes & Yes \\
Controls & Yes & Yes & Yes \\
Sample & Unmatched & Propensity & Entropy \\
Observations & 28,459 & 10,476 & 28,438 \\
Adjusted R & 0.267 & 0.258 & 0.267 \\
\hline
\end{tabular}

This table reports OLS regression results. The dependent variable is the number of manager forecasts (\#Fore). Controls include LogMVE, BTM, LogAge, ROA, OP, RE, EarnVol, RetVol, and Inst\%. Robust standard errors are clustered by firm. T-statistics are reported in parentheses. ***, **, and * denote statistical significance at the $1 \%, 5 \%$, and $10 \%$ levels for two-tailed tests, respectively. Sample selection procedures are reported in Table 1. Variable definitions are reported in Appendix Table 13. The bolded variable names and coefficients are the key variables of interest

1994; Feng and McVay 2010). ${ }^{16}$ We examine whether dividend paying firms provide less guidance using the following model:

$$
\text { \#Fore }_{i, t+1}=\beta_{0}+\beta_{1} D I V_{i, t}+\gamma_{k} \text { CONTROLS }_{i, t}+\omega_{k} \text { YEAR } * I N D \_F E_{i, t}+\varepsilon
$$

where \#Fore is the natural logarithm of one plus the number of managerial forecasts issued in year $t+1$. We exclude firm-years with no guidance and we include management forecasts of all items except dividend and capital expenditure forecasts. ${ }^{17}$ Managers have broad discretion to determine both dividends and capital expenditures, in contrast to items like revenues and earnings, which require transactions with customers and suppliers. We exclude these forecasts from our sample because we expect that the discretionary nature of the reported number will lead to less pressure to meet the benchmark or to influence analysts. CONTROLS include our nine main control variables. We also include industry by year fixed effects.

Table 12 reports the results. In columns (1)-(3), the independent variable is the dividend indicator, $D I V$, in each of the three samples (unmatched, PSM, and entropy balanced). The coefficient on $D I V$ is negative and statistically significant in all three columns, consistent with our expectation that dividend payers issue less management guidance.

\footnotetext{
${ }^{16}$ It is also possible that payers' weaker focus on earnings, discussed in the prior section, reduces their willingness to incur the cost to provide forecasts (e.g., because dividends already provide information).

${ }^{17}$ Because this test uses firm-years rather than firm quarters, the sample is smaller than in our other tests.
} 


\section{Conclusion}

For 60 years, researchers have been investigating the dividend puzzle - the reason firms pay dividends in spite of their irrelevance for valuation (Miller and Modigliani 1961; Black 1976). Managers pay dividends only when the benefits exceed the costs, but researchers have been more successful at documenting the costs (e.g., the tax disadvantage) than the benefits. Further, investors impose penalties on managers for cutting dividends, and managers make sub-optimal investment decisions in attempting to avoid cuts (Brav et al. 2005; Wu 2018). Numerous studies show that removing excess cash from the control of the manager increases firm value, but share buybacks can accomplish this without the costly implicit commitment to maintain the dividend. In addition, in most settings, it does not appear that dividends are funded out of foregone investment (Fama 1974; Isakov et al. 2021; Kaplan and Perez-Cavazos 2021).

In this paper, we hypothesize that by paying a dividend, managers signal the level of permanent earnings to investors, which substitutes for earnings information from other sources. Consistent with this, we find that dividends rationally reduce investors' attention to payers' EAs and that dividend payers correspondingly engage in lower levels of costly earnings management relative to non-dividend payers. Collectively, this suggests that dividends impact the information environment and, despite being costly, could be an efficient way for some firms to meet investors' demands for earnings information. Broadly, our evidence highlights important and previously unexplored interdependencies in the information environment (Beyer et al. 2010).

However, our analysis on the heterogeneity in the extent to which dividends substitute for earnings information suggests that not all dividends convey permanent earnings information. Specifically, firms with greater cash holdings to fund the dividend, firms with a high likelihood of cutting the dividend, and firms with a low yield have similar market reactions to earnings as non-payers. Thus, our analysis suggests that other determinants, such as clientele effects (e.g., Allen et al. 2000), could explain the decision to pay a dividend for a substantial set of dividend payers. 


\section{Appendix}

Table 13 Variable definitions

\begin{tabular}{|c|c|}
\hline Variable & Definition \\
\hline \multicolumn{2}{|l|}{ Dependent Variables } \\
\hline$C A R_{i, q}$ & $\begin{array}{l}\text { Equals the abnormal return around firm } i \text { 's quarter } q \text { earnings announcement } \\
(\text { day }=0) \text {, defined as the } 3 \text {-day market-adjusted abnormal earnings announce- } \\
\text { ment return }\left(\sum_{\mathrm{day}=-1}^{1}(\text { ret }- \text { vwretd })\right) \text {. }\end{array}$ \\
\hline CAR at DIV $V_{i, q+1}$ & $\begin{array}{l}\text { Equals the abnormal return around firm } i \text { 's quarter } q+1 \text { dividend announcement } \\
(\text { day }=0) \text {, defined as the } 3 \text {-day market-adjusted abnormal announcement return } \\
\left(\sum_{\text {day }=-1}^{1}(\text { ret }- \text { vwretd })\right)\end{array}$ \\
\hline $\operatorname{Earn}_{i, t+1}$ & $\begin{array}{l}\text { Equals the sum of earnings per share for firm } i \text { over quarters } q+1 \text { to } q+4 \text {, scaled } \\
\text { by price at the beginning of quarter } q \text {. }\end{array}$ \\
\hline$E A \_\operatorname{Ret}_{i, q}$ & $\begin{array}{l}\text { Equals the natural logarithm of } 100 * N E W S \_R A T I O . N E W S \_R A T I O \\
\text { equals the sum of the absolute values of the daily market-adjusted returns } \\
\text { ( } \sum \text { abs }(\text { ret-vwretd)) from one day before the quarter } q \text { earnings announcement } \\
\text { to one day after the quarter } q \text { earnings announcement }(E A R) \text { scaled by the } \\
\text { absolute value of the daily market-adjusted non-earnings announcement returns } \\
\left.(N E A R) \text { (i.e., } N E W S \_R A T I O=E A R / N E A R\right) \text {. NEAR equals the sum of the abso- } \\
\text { lute values of the daily market-adjusted return over the quarter }(Q R E T) \text { from } \\
\text { two days after the quarter } q-1 \text { earnings announcement to one day after the quar- } \\
\text { ter } q \text { earnings announcement adjusted by the EAR (i.e., } N E A R=(1+Q R E T) / \\
(1+E A R)-1) \text { following Roychowdhury and Sletten }(2012) \text {. }\end{array}$ \\
\hline$E A_{-} V_{o l} l_{i, q}$ & $\begin{array}{l}\text { Equals the natural logarithm of } 100 * N E W S_{-} R A T I O \_V O L . N E W S_{-} R A T I O \_V O L \\
\text { equals the trading volume from one day before the quarter } q \text { earnings } \\
\text { announcement to one day after the quarter } q \text { earnings announcement }(E A V) \\
\text { scaled by the non-earnings announcement trading volume }(N E A V) \text { (i.e., } N E W S \\
\left.R A T I O \_V O L=E A V / N E A V\right) \text {. } N E A V \text { equals the total trading volume over the } \\
\text { quarter }(Q V O L) \text { from two days after the quarter } q-1 \text { earnings announcement } \\
\text { to one day after the quarter } q \text { earnings announcement, adjusted by the } E A V \\
\text { (i.e., } N E A V=(1+Q V O L) /(1+E A V)-1) \text { following Roychowdhury and Sletten } \\
\text { (2012). }\end{array}$ \\
\hline$E A_{-} A F_{i, q}$ & $\begin{array}{l}\text { Equals the percentage of analysts' earnings per share forecasts occurring in the } \\
\text { EA window relative to the entire quarter }(E A F / Q F O R) \text {. We calculate this as } \\
\text { the number of forecasts occurring from one day before the quarter } q \text { earnings } \\
\text { announcement to one day after the quarter } q \text { earnings announcement }(E A F) \\
\text { scaled by total number of forecasts during the quarter }(Q F O R) \text { from two days } \\
\text { after the quarter } q-1 \text { earnings announcement to one day after the quarter } q \\
\text { earnings announcement. We calculate the EA forecasts as a percentage of total } \\
\text { forecasts rather than of non-earnings announcement forecasts because, unlike } \\
\text { returns and volume, forecasts can be zero during the non-earnings announce- } \\
\text { ment period. }\end{array}$ \\
\hline
\end{tabular}

$\operatorname{Surp}[X]_{i, q}$

Represents a series of indicator variables to capture earnings that fall just above or below the median of the outstanding consensus forecast. For example, Surp [-1] is set to one if the forecast error falls in the range [-0.01,0.00), Surp [0] is set to one if the forecast error is equal to zero, and Surp [1] is set to one if the forecast error falls in the range $(0.00,0.01]$.

$\operatorname{Surp}[-3,3]_{i, q}$

Equals negative one if the forecast error falls in the range $[-0.03,0.00)$, positive one if the forecast error falls in the range [0.00,0.03], and zero otherwise.

$\operatorname{Surp}[7,13]_{i, q}$

Equals negative one if the forecast error falls in the range $[0.07,0.10)$, positive one if the forecast error falls in the range [0.10,0.13], and zero otherwise.

Change in $R \& D$ expenses $(\Delta R \& D)$, revenue $(\Delta R e v)$, or accounts receivable $(\Delta \mathrm{AR})$, computed as the difference between amount reported in the current quarter and the amount reported same time last year, scaled by total assets. 
Table 13 (continued)

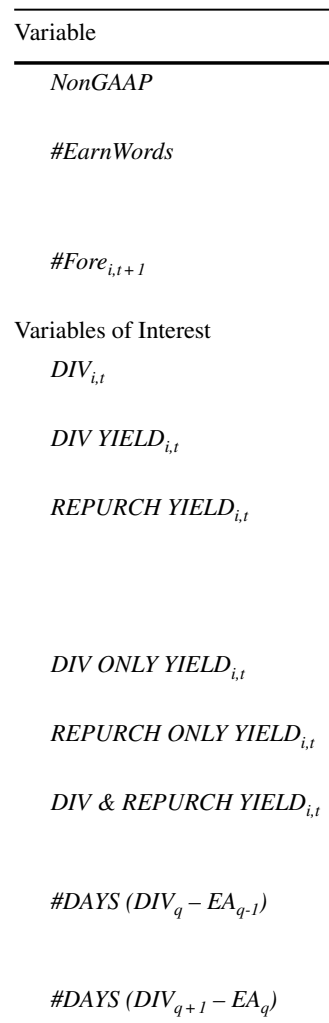

Definition

Indicator set equal to one if the firm issued a non-GAAP earnings release for the current quarter. Data downloaded from Kurt Gee's website.

Number of earnings words in the presentation section of the conference call. Conference call data downloaded from Seeking Alpha by Kimball Chapman. Earnings words defined as "Earnings," "EPS," and "Net Income"

Equals the natural logarithm of one plus the number of $\mathrm{I} / \mathrm{B} / \mathrm{E} / \mathrm{S}$ manager forecasts for firm $i$ in year $t+1$, excluding dividend and capital expenditure forecasts.

Indicator variable that equals one if firm $i$ paid a dividend in year $t$ and zero otherwise.

Equals the quarterly dividend yield as of the end of year $t$ annualized to represent a full year equivalent amount.

Prior to 2004, equals purchases of common and preferred shares scaled by $M V E$ for firm $i$ in year $t$ (PRSTKC/MVE). For 2004 and later, equals annualized fourth quarter repurchases scaled by $M V E$ for firm $i$ in year $t$ ([CSHOPQ*PRCRAQ*4]/MVE). CSHOPQ is only available in 2004 and later. See Banyi et al. (2005). If missing either numerator, we set it equal to 0.

Equals DIV YIELD if firm $i$ only pays dividends in year $t$ (i.e., DIV YIELD $>0$ and REPURCH YIELD $=0$ ), and 0 otherwise.

Equals REPURCH YIELD if firm $i$ only makes repurchases in year $t$ (i.e., DIV $Y I E L D=0$ and REPURCH YIELD $>0$ ), and 0 otherwise.

Equals DIV YIELD plus REPURCH YIELD if firm $i$ both pays dividends and makes repurchases in year $t$ (i.e., DIV YIELD $>0$ and REPURCH YIELD $>0$ ), and 0 otherwise.

Equals the time between firm $i$ 's earnings announcement for quarter $q-1$ and the dividend declaration date (dclrdt) prior to the quarter $q$ earnings announcement. This variable is then scaled so that all values fall between 0 and 1 .

Equals the time between firm $i$ 's earnings announcement for quarter $q$ and the dividend declaration date (dclrdt) subsequent to the quarter $q$ earnings announcement. This variable is then scaled so that all values fall between 0 and 1 .

Control Variables

${\log M V E_{i, t}}$

$B T M_{i, t}$

Equals the natural logarithm of $(1+M V E)$ for firm $i$ in year $t$. MVE equals firm $i$ 's market value of equity from CRSP, converted to millions of dollars to match Compustat ([prc*shrout]/1000), at the end of year $t$.

Equals firm $i$ 's book equity to market equity $(M V E)$ as of the end of year $t$. Book equity equals Compustat's common shareholders' equity (CEQ) plus deferred taxes (TXDB) plus investment tax credit (ITCB). If CEQ is missing, we replace CEQ with total shareholders' equity (SEQ) minus preferred stock (the first available of PSTKRV, PSTKL, or PSTK). If SEQ is missing, we calculate total shareholders' equity (AT - LT). If TXDB, ITCB, or preferred stock are missing, we set them to zero. $M V E$ is described above.

$\operatorname{LogAge}_{i, t}$

$R O A_{i, t}$

$O P_{i, t}$

Equals the natural logarithm of $(1+A g e)$ for firm $i$ in year $t$. Age equals the number of years that firm $i$ has appeared on Compustat as of the end of year $t$.

Equals firm $i$ 's return on assets (OIADP/AT) at the end of year $t$.

Equals the firm $i$ 's operating profitability in year $t$ (REVT - COGS - (XSGA XRD) - XINT) scaled by book equity as defined in the BTM calculation. We remove $R \& D$ expense from $S G \& A$ expenses. If any item is missing, we set it to 0 .

$R E_{i, t}$

EarnVol $_{i, t}$

Equals firm $i$ 's total retained earnings scaled by assets (RE/AT) at the end of year $t$.

Equals the standard deviation of firm i's income (IB) from year $t$ to year $t-4$, requiring all 5 years of data, scaled by assets (AT) at the end of year $t$ (Dichev and Tang 2009). 
Table 13 (continued)

\begin{tabular}{|c|c|}
\hline Variable & Definition \\
\hline $\operatorname{RetVol}_{i, t}$ & $\begin{array}{l}\text { Equals the average of the absolute value of the daily abnormal return for firm } i \text { in } \\
\text { year } t\left(\left[\left(\sum_{\text {year } t} a b s(\text { ret }- \text { vwretd })\right] / \text { number of daily returns over year } t\right) .\right.\end{array}$ \\
\hline $\operatorname{Inst} \%_{i, t}$ & Equals the percentage of institutional ownership for firm $i$ in year $t$. \\
\hline$U E_{i, q}$ & $\begin{array}{l}\text { The decile rank, by year, of the value of the I/B/E/S actual earnings minus the } \\
\text { I/B/E/S analysts' most recent median quarterly earnings forecast for firm } i \text { in } \\
\text { quarter } q \text {, scaled by stock price at the beginning of quarter } q \text {. To ease interpreta- } \\
\text { tion, we scale the decile rank to range between } 0 \text { (lowest decile) and } 1 \text { (highest } \\
\text { decile). }\end{array}$ \\
\hline$D I V C H G_{i, q}$ & $\begin{array}{l}\text { The decile rank, by year, of the dividend change from quarter } q \text { - } 1 \text { to quarter } q \text { for } \\
\text { firm } i \text { in quarter } q \text {. We measure the dividend change as: [(quarter } q \text { dividend - } \\
\text { quarter } q-1 \text { dividend) / (quarter } q \text { dividend + quarter } q-1 \text { dividend)]. We scale } \\
\text { by the sum to prevent small denominator problems. To ease interpretation, we } \\
\text { scale the decile rank to range between } 0 \text { (lowest decile) and } 1 \text { (highest decile). }\end{array}$ \\
\hline$E A \_D e l a y_{i, q}$ & $\begin{array}{l}\text { Equals the number of days between the fiscal period end date for firm } i \text { in quarter } \\
q \text { and the announcement of quarter } q \text { 's earnings. }\end{array}$ \\
\hline$P R(C U T)_{i, t}$ & $\begin{array}{l}\text { Equals firm } i \text { 's propensity to cut the dividend at the end of year } t \text {. We estimate the } \\
\text { propensity to cut the dividend using our base set of nine control variables. We } \\
\text { also include separate indicators for negative earnings and returns in year } t \text {, the } \\
\text { most recent } 12 \text {-month return, and industry and year fixed effects. We then cal- } \\
\text { culate the propensity to cut the dividend as the fitted value from the first stage } \\
\text { model. We decile rank this propensity by year, and scale it to range between } 0 \\
\text { and } 1 \text { to ease interpretation. }\end{array}$ \\
\hline$C A S H_{i, t}$ & $\begin{array}{l}\text { Equals firm } i \text { 's cash and cash equivalents scaled by assets (CHE/AT) at the end } \\
\text { of year } t \text {. }\end{array}$ \\
\hline \#Analyst $_{i, q}$ & $\begin{array}{l}\text { Equals the natural logarithm of one plus the number of analysts in the consensus } \\
\text { forecast for firm } i \text { in quarter } q \text {. }\end{array}$ \\
\hline
\end{tabular}

Acknowledgements The authors appreciate helpful comments from an anonymous reviewer, Steve Baginski, Matthias Breuer, Kimball Chapman, Rich Frankel, Todd Gormley, Lisa Hinson, Todd Kravet, Mark Leary, Andy Leone (discussant), Alina Lerman, Stephen Penman (editor), K. Ramesh, Jake Thomas, Dave Weber, Ying Zhou, and workshop participants at Columbia University, Northwestern University, the University of Connecticut, the University of Oregon, and the Dopuch Conference at Washington University in St. Louis. We thank Kimball Chapman for providing data on earnings mentions in conference calls. Utke gratefully acknowledges funding from the University of Connecticut School of Business Dean's Fund.

Data availability Data used in this study are available from the public sources identified in the paper.

Open Access This article is licensed under a Creative Commons Attribution 4.0 International License, which permits use, sharing, adaptation, distribution and reproduction in any medium or format, as long as you give appropriate credit to the original author(s) and the source, provide a link to the Creative Commons licence, and indicate if changes were made. The images or other third party material in this article are included in the article's Creative Commons licence, unless indicated otherwise in a credit line to the material. If material is not included in the article's Creative Commons licence and your intended use is not permitted by statutory regulation or exceeds the permitted use, you will need to obtain permission directly from the copyright holder. To view a copy of this licence, visit http://creativecommons.org/licen ses/by/4.0/. 


\section{References}

Abramova, Inna, John E. Core, and Andrew Sutherland. (2020). Institutional investor attention and firm disclosure. The Accounting Review 95 (6): 1-21. https://doi.org/10.2308/tar-2018-0494.

Aharony, Joseph, and Amihud Dotan. (1994). Regular dividend announcements and future unexpected earnings: An empirical analysis. Financial Review 29 (1): 125-151. https://doi.org/10.1111/j.15406288.1994.tb00816.x.

Ajinkya, Bipin B., and Michael J. Gift. (1984). Corporate managers' earnings forecasts and symmetrical adjustments of market expectations. Journal of Accounting Research 22 (2): 425-444. https://doi. org/10.2307/2490657.

Ali, Ashiq, and Paul Zarowin. (1992). Permanent versus transitory components of annual earnings and estimation error in earnings response coefficients. Journal of Accounting and Economics 15 (2-3): 249-264. https://doi.org/10.1016/0165-4101(92)90020-3.

Allen, Franklin, and Roni Michaely. (2003). Chapter 7: Payout policy. In Handbook of the economics of finance: Volume 1, part A, ed. George M. Constantinides, Milton Harris, and René M. Stulz, 337-429. Elsevier.

Allen, Franklin, Antonio E. Bernardo, and Ivo Welch. (2000). A theory of dividends based on tax clienteles. The Journal of Finance 55 (6): 2499-2536. https://doi.org/10.1111/0022-1082.00298.

Angrist, Joshua D., and Jörn-Steffen Pischke. (2009). Mostly harmless econometrics: An empiricist's companion. Princeton University Press.

Ayers, Benjamin C., Casey M. Schwab, and Steven Utke. (2015). Noncompliance with mandatory disclosure requirements: The magnitude and determinants of undisclosed permanently reinvested earnings. The Accounting Review 90 (1): 59-93. https://doi.org/10.2308/accr-50853.

Bamber, Linda Smith. (1986). The information content of annual earnings releases: A trading volume approach. Journal of Accounting Research 24 (1): 40-56. https://doi.org/10.2307/2490803.

Banyi, Monica, Edward A. Dyl, and Kathleen M. Kahle. (2005). Measuring share repurchases. Working paper. https://doi.org/10.2139/ssrn.726284.

Bartov, Eli, Dan Givoly, and Carla Hayn. (2002). The rewards to meeting or beating earnings expectations. Journal of Accounting and Economics 33 (2): 173-204. https://doi.org/10.1016/S01654101(02)00045-9.

Beardsley, Eric L., Nathan C. Goldman, and Thomas C. Omer. (2020). Audit office industry diversity and audit quality. Journal of Accounting, Auditing and Finance. https://doi.org/10.1177/0148558X20 942618.

Beaver, William H. (1968). The information content of annual earnings announcements. Journal of Accounting Research 6: 67-92. https://doi.org/10.2307/2490070.

Benartzi, Shlomo, Roni Michaely, and Richard Thaler. (1997). Do changes in dividends signal the future or the past? The Journal of Finance 52 (3): 1007-1034. https://doi.org/10.1111/j.1540-6261.1997. tb02723.x.

Bentley, Jeremiah W., Theodore E. Christensen, Kurt H. Gee, and Benjamin C. Whipple. (2018). Disentangling managers' and analysts' non-GAAP reporting. Journal of Accounting Research 56 (4): 1039-1081. https://doi.org/10.1111/1475-679X.12206.

Bernard, Victor L., and Jacob K. Thomas. (1990). Evidence that stock prices do not fully reflect the implications of current earnings for future earnings. Journal of Accounting and Economics 13 (4): 305-340. https://doi.org/10.1016/0165-4101(90)90008-R.

Beyer, Anne, Daniel A. Cohen, Thomas Z. Lys, and Beverly R. Walther. (2010). The financial reporting environment: Review of the recent literature. Journal of Accounting and Economics 50 (2-3): 296-343. https://doi.org/10.1016/j.jacceco.2010.10.003.

Bhojraj, Sanjeev, Paul Hribar, Marc Picconi, and John McInnis. (2009). Making sense of cents: An examination of firms that marginally miss or beat analyst forecasts. The Journal of Finance 64 (5): 23612388. https://doi.org/10.1111/j.1540-6261.2009.01503.x.

Bird, Andrew, Stephen A. Karolyi, and Thomas G. Ruchti. (2019). Understanding the "numbers game". Journal of Accounting and Economics 68 (2-3): 101242. https://doi.org/10.1016/j.jacceco.2019. 101242.

Black, Fischer. (1976). The dividend puzzle. Journal of Portfolio Management 2 (2): 5-8.

Blankespoor, Elizabeth, Ed deHaan, and Ivan Marinovic. (2020). Disclosure processing costs, investors' information choice, and equity market outcomes. Journal of Accounting and Economics 70 (2-3). https://doi.org/10.1016/j.jacceco.2020.101344. 
Bolton, Patrick, Hui Chen, and Neng Wang. (2011). A unified theory of Tobin's q, corporate investment, financing, and risk management. The Journal of Finance 66 (5): 1545-1578. https://doi.org/10. 1111/j.1540-6261.2011.01681.x.

Bratten, Brian, Stephannie A. Larocque, and Teri Lombardi Yohn. (2020). On the informativeness of unexpected exclusions from street earnings. Working paper. https://doi.org/10.2139/ssrn.3470390.

Brav, Alon, John Graham, Campbell Harvey, and Roni Michaely. (2005). Payout policy in the $21^{\text {st }}$ century. Journal of Financial Economics 77 (3): 483-527. https://doi.org/10.1016/j.jfineco.2004.07. 004.

Burgstahler, David, and Ilia Dichev. (1997). Earnings management to avoid earnings decreases and losses. Journal of Accounting and Economics 24 (1): 99-126. https://doi.org/10.1016/S01654101(97)00017-7.

Caskey, Judson, and Michelle Hanlon. (2013). Dividend policy at firms accused of accounting fraud. Contemporary Accounting Research 30 (2): 818-850. https://doi.org/10.1111/j.1911-3846.2012. 01173.x.

Chay, Jong-Bom, and Jungwon Suh. (2009). Payout policy and cash-flow uncertainty. Journal of Financial Economics 93 (1): 88-107. https://doi.org/10.1016/j.jfineco.2008.12.001.

Chen, Shuping, Terry Shevlin, and Yen H. Tong. (2007). Does the pricing of financial reporting quality change around dividend changes? Journal of Accounting Research 45 (1): 1-40. https://doi.org/10. 1111/j.1475-679X.2007.00225.x.

Cho, Young Jun, Yongtae Kim, and Yoonseok Zang. (2020). Information externalities and voluntary disclosure: Evidence from a major customer's earnings announcement. The Accounting Review 95 (6): 73-96. https://doi.org/10.2308/tar-2017-0129.

Christensen, Theodore E., Kenneth J. Merkley, Jennifer Wu Tucker, and Shankar Venkataraman. (2011). Do managers use earnings guidance to influence street earnings exclusions? Review of Accounting Studies 16: 501-527. https://doi.org/10.1007/s11142-011-9158-3.

DeAngelo, Harry, Linda DeAngelo, and Douglas J. Skinner. (1992). Dividends and losses. The Journal of Finance 47 (5): 1837-1863. https://doi.org/10.1111/j.1540-6261.1992.tb04685.x.

DeAngelo, Harry, Linda DeAngelo, and Douglas J. Skinner. (1996). Reversal of fortune, dividend signaling, and the disappearance of sustained earnings growth. Journal of Financial Economics 40 (3): 341-371. https://doi.org/10.1016/0304-405X(95)00850-E.

DeAngelo, Harry, Linda DeAngelo, and René M. Stulz. (2006). Dividend policy and the earned/contributed capital mix: A test of the life-cycle theory. Journal of Financial Economics 81 (2): 227-254. https://doi.org/10.1016/j.jfineco.2005.07.005.

DeAngelo, Harry, Linda DeAngelo, and Douglas J. Skinner. (2009). Corporate payout policy. Foundations and Trends in Finance 3 (2-3): 95-287. https://doi.org/10.1561/0500000020.

DeFond, Mark, David H. Erkens, and Jieying Zhang. (2017). Do client characteristics really drive the big $\mathrm{N}$ audit quality effect? New evidence from propensity score matching. Management Science 63 (11): 3628-3649. https://doi.org/10.1287/mnsc.2016.2528.

Degeorge, Francois, Jayendu Patel, and Richard Zeckhauser. (1999). Earnings management to exceed thresholds. The Journal of Business 72 (1): 1-33. https://doi.org/10.1086/209601.

deHaan, Ed, Terry Shevlin, and Jacob Thornock. (2015). Market (in)attention and the strategic scheduling and timing of earnings announcements. Journal of Accounting and Economics 60 (1): 36-55. https://doi.org/10.1016/j.jacceco.2015.03.003.

Del Guercio, Diane. (1996). The distorting effect of the prudent-man laws on institutional equity investments. Journal of Financial Economics 40 (1): 31-62. https://doi.org/10.1016/0304-405X(95) 00841-2.

Denis, David J., and Igor Osobov. (2008). Why do firms pay dividends? International evidence on the determinants of dividend policy. Journal of Financial Economics 89 (1): 62-82. https://doi.org/10. 1016/j.jfineco.2007.06.006.

Dichev, Ilia D., and Vicki Wei Tang. (2009). Earnings volatility and earnings predictability. Journal of Accounting and Economics 47 (1-2): 160-181. https://doi.org/10.1016/j.jacceco.2008.09.005.

Dimon, Jamie, and Warren E. Buffett. (2018). Short-termism is harming the economy. The Wall Street Journal (June 6) https://www.wsj.com/articles/short-termism-is-harming-the-economy-15283 36801.

Doyle, Jeffrey T., Jared N. Jennings, and Mark T. Soliman. (2013). Do managers define non-GAAP earnings to meet or beat analyst forecasts? Journal of Accounting and Economics 56 (1): 40-56. https:// doi.org/10.1016/j.jacceco.2013.03.002. 
Easterbrook, Frank H. (1984). Two agency-cost explanations of dividends. The American Economic Review 74 (4): 650-659.

Easton, Peter D., and Mark E. Zmijewski. (1989). Cross-sectional variation in the stock market response to accounting earnings announcements. Journal of Accounting and Economics 11 (2-3): 117-141. https://doi.org/10.1016/0165-4101(89)90003-7.

Ellahie, Atif, and Zachary Kaplan. (2021). Show me the money! Dividend policy in countries with weak institutions. Journal of Accounting Research 59 (2): 613-655. https://doi.org/10.1111/1475-679X. 12363.

Fama, Eugene F. (1974). The empirical relationship between the dividend and investment decisions of firms. American Economic Review 64 (3): 304-318.

Fama, Eugene F., and Kenneth R. French. (1998). Taxes, financing decisions, and firm value. The Journal of Finance 53 (3): 819-843. https://doi.org/10.1111/0022-1082.00036.

Fama, Eugene F., and Kenneth R. French. (2000). Forecasting profitability and earnings. The Journal of Business 73 (2): 161-175. https://doi.org/10.1086/209638.

Farre-Mensa, Joan, Roni Michaely, and Martin C. Schmalz. (2014). Payout policy. Annual Review of Financial Economics 6: 745-134. https://doi.org/10.1146/annurev-financial-110613-034259.

Faulkender, Michael, and Rong Wang. (2006). Corporate financial policy and the value of cash. The Journal of Finance 61 (4): 1957-1990. https://doi.org/10.1111/j.1540-6261.2006.00894.x.

Feltham, Gerald A., and James A. Ohlson. (1995). Valuation and clean surplus accounting for operating and financial activities. Contemporary Accounting Research 11 (2): 689-731. https://doi.org/10. 1111/j.1911-3846.1995.tb00462.x.

Feng, Mei, and Sarah McVay. (2010). Analysts' incentives to overweight management guidance when revising their short-term earnings forecasts. The Accounting Review 85 (5): 1617-1646. https://doi. org/10.2308/accr.2010.85.5.1617.

Gipper, Brandon, Christian Leuz, and Mark Maffett. (2020). Public oversight and reporting credibility: Evidence from the PCAOB audit inspection regime. The Review of Financial Studies 33 (10): 4532 4579. https://doi.org/10.1093/rfs/hhz149.

Gleason, Cristi A., and Lillian F. Mills. (2008). Evidence of differing market responses to beating analysts' targets through tax expense decreases. Review of Accounting Studies 13: 295-318. https://doi. org/10.1007/s11142-007-9066-8.

Graham, John R., Campbell R. Harvey, and Shiva Rajgopal. (2005). The economic implications of corporate financial reporting. Journal of Accounting and Economics 40 (1-3): 3-73. https://doi.org/10. 1016/j.jacceco.2005.01.002.

Grinstein, Yaniv, and Roni Michaely. (2005). Institutional holdings and payout policy. The Journal of Finance 60 (3): 1389-1426. https://doi.org/10.1111/j.1540-6261.2005.00765.x.

Grullon, Gustavo, Roni Michaely, and Bhaskaran Swaminathan. (2002). Are dividend changes a sign of firm maturity? The Journal of Business 75 (3): 387-424. https://doi.org/10.1086/339889.

Guay, Wayne, and Jarrad Harford. (2000). The cash-flow permanence and information content of dividend increases versus repurchases. Journal of Financial Economics 57 (3): 385-415. https://doi.org/ 10.1016/S0304-405X(00)00062-3.

Hail, Luzi, Ahmed Tahoun, and Clare Wang. (2014). Dividend payouts and information shocks. Journal of Accounting Research 52 (2): 403-456. https://doi.org/10.1111/1475-679X.12040.

Hainmueller, Jens. (2012). Entropy balancing for causal effects: A multivariate reweighting method to produce balanced samples in observational studies. Political Analysis 20 (1): 25-46. https://doi.org/ 10.1093/pan/mpr025.

Hainmueller, Jens, and Yiqing Xu. (2013). Ebalance: A Stata package for entropy balancing. Journal of Statistical Software 54 (7): 1-18.

Ham, Charles, Zachary Kaplan, and Mark Leary. (2020). Do dividends convey information about future earnings? Journal of Financial Economics 136: 547-570. https://doi.org/10.1016/j.jfineco.2019.10. 006.

Healy, Paul M., and Krishna G. Palepu. (2001). Information asymmetry, corporate disclosure, and the capital markets: A review of the empirical disclosure literature. Journal of Accounting and Economics 31 (1-3): 405-440. https://doi.org/10.1016/S0165-4101(01)00018-0.

Hershberger, Scott L. (2011). Hodges-Lehmann estimators. In International encyclopedia of statistical science, ed. Miodrag Lovric, 635-636. Springer.

Hosmer, Jr, W. David, Stanley Lemeshow, and Rodney X. Sturdivant. (2013). Applied logistic regression. 3rd ed. Wiley. 
Hribar, Paul, Nicole Thorne Jenkins, and W. Bruce Johnson. (2006). Stock repurchases as an earnings management device. Journal of Accounting and Economics 41 (1-2): 3-27. https://doi.org/10. 1016/j.jacceco.2005.10.002.

Isakov, Dušan, Christophe Pérignon, and Jean-Phillipe Weisskopf. (2021). What if dividends were taxexempt? Evidence from a natural experiment. The Review of Financial Studies forthcoming. https:// doi.org/10.1093/rfs/hhab010.

Jensen, Michael C. (1986). Agency costs of free cash flow, corporate finance, and takeovers. The American Economic Review 76 (2): 323-329.

Kalay, Avner, and Michael Lemmon. (2008). Payout policy. In Handbook of empirical corporate finance, volume 2, ed. B. Espen Eckbo, 4-50. Elsevier.

Kallapur, Sanjay. (1994). Dividend payout ratios as determinants of earnings response coefficients. Journal of Accounting and Economics 17 (3): 359-375. https://doi.org/10.1016/0165-4101(94) 90033-7.

Kaplan, Zachary R. and Gerardo Perez-Cavazos. (2021). Investment opportunities as the cost of dividend signaling. The Accounting Review.

Kim, Oliver, and Robert E. Verrecchia. (1991). Trading volume and price reactions to public announcements. Journal of Accounting Research 29 (2): 302-321. https://doi.org/10.2307/24910 51.

Kim, Mark P., Spencer R. Pierce, and Ira Yeung. (2021). Why firms announce good new late: Earnings management and financial reporting timeliness. Contemporary Accounting Research forthcoming. https://doi.org/10.1111/1911-3846.12695.

Levitt, Arthur. (1998). Remarks: The 'numbers game.' NYU Center for Law and Business, September 28. https://www.sec.gov/news/speech/speecharchive/1998/spch220.txt. Accessed 19 May 2021.

Lintner, John. (1956). Distribution of incomes of corporations among dividends, retained earnings, and taxes. The American Economic Review 46 (2): 97-113.

Matsunaga, Steven R., and Chul W. Park. (2001). The effect of missing a quarterly earnings benchmark on the CEO's annual bonus. The Accounting Review 76 (3): 313-332. https://doi.org/10. 2308/accr.2001.76.3.313.

McMullin, Jeff L., and Bryce Schonberger. (2020). Entropy-balanced discretionary accruals. Review of Accounting Studies 25: 84-119. https://doi.org/10.1007/s11142-019-09525-9.

Michaely, Roni, Stefano Rossi, and Michael Weber. (2021). Signaling safety. Journal of Financial Economics 139: 405-427. https://doi.org/10.1016/j.jfineco.2020.08.013.

Miller, Merton H., and Franco Modigliani. (1961). Dividend policy, growth, and the valuation of shares. The Journal of Business 34 (4): 411-433.

Myers, Stewart C., and Nicholas S. Majluf. (1984). Corporate financing and investment decisions when firms have information that investors do not have. Journal of Financial Economics 13 (2): 187-221. https://doi.org/10.1016/0304-405X(84)90023-0.

Noh, Suzie, Eric C. So, and Rodrigo S. Verdi. (2021). Calendar rotations: A new approach for studying the impact of timing using earnings announcements. Journal of Financial Economics 140: 865-893. https://doi.org/10.1016/j.jfineco.2021.01.009.

Payne, Jeff L., and Wayne B. Thomas. (2003). The implications of using stock-split adjusted I/B/E/S data in empirical research. The Accounting Review 78 (4): 1049-1067. https://doi.org/10.2308/ accr.2003.78.4.1049.

Penman, Stephen H., and Theodore Sougiannis. (1997). The dividend displacement property and the substitution of anticipated earnings for dividends in equity valuation. The Accounting Review 72 (1): $1-21$.

Penman, Stephen H., and Nir Yehuda. (2019). A matter of principle: Accounting reports convey both cash-flow news and discount-rate news. Management Science 65 (12): 5584-5602. https://doi. org/10.1287/mnsc.2018.3187.

Roberts, Michael R., and Toni M. Whited. (2013). Endogeneity in empirical corporate finance. In Handbook of the economics of finance, volume 2A, ed. George M. Constantinides, Milton Harris, and René M. Stulz, 493-572. Elsevier.

Robinson, David, and Denys Glushkov. (2006). A note on IBES unadjusted data. Wharton Research Data Services. https://wrds-www.wharton.upenn.edu/documents/5/A_Note_on_IBES_Unadj usted_Data_pdf.pdf Accessed 19 May 2021.

Roychowdhury, Sugata, and Ewa Sletten. (2012). Voluntary disclosure incentives and earnings informativeness. The Accounting Review 87 (5): 1679-1708. https://doi.org/10.2308/accr-50189. 
Shipman, Jonathan E., Quinn T. Swanquist, and Robert L. Whited. (2017). Propensity score matching in accounting research. The Accounting Review 92 (1): 213-244. https://doi.org/10.2308/ accr-51449.

Sivakumar, Kumar N., and Gregory Waymire. (1993). The information content of earnings in a discretionary reporting environment: Evidence from NYSE industrials, 1905-10. Journal of Accounting Research 31 (1): 62-91. https://doi.org/10.2307/2491042.

Skinner, Douglas J. (1994). Why firms voluntarily disclose bad news. Journal of Accounting Research 32 (1): 38-60. https://doi.org/10.2307/2491386.

Skinner, Douglas J. (2008). The evolving relation between earnings, dividends, and stock repurchases. Journal of Financial Economics 87 (3): 582-609. https://doi.org/10.1016/j.jfineco.2007.05.003.

Skinner, Douglas J., and Richard G. Sloan. (2002). Earnings surprises, growth expectations, and stock returns or don't let an earnings torpedo sink your portfolio. Review of Accounting Studies 7 (2-3): 289-312. https://doi.org/10.1023/A:1020294523516.

Skinner, Douglas J., and Eugene Soltes. (2011). What do dividends tell us about earnings quality? Review of Accounting Studies 16 (1): 1-28. https://doi.org/10.1007/s11142-009-9113-8.

Stein, Jeremy C. (1989). Efficient capital markets, inefficient firms: A model of myopic corporate behavior. The Quarterly Journal of Economics 104 (4): 655-669. https://doi.org/10.2307/2937861.

Stubben, Stephen R. (2010). Discretionary revenues as a measure of earnings management. The Accounting Review 85 (2): 695-717. https://doi.org/10.2308/accr.2010.85.2.695.

Sul, Edward. (2020). Effects of Fintech and crowdsourced forecasting on firms: Evidence from Estimize. Working paper. https://doi.org/10.2139/ssrn.3573152.

Sun, Chenzhu, Shujing Wang, and Chu Zhang. (2020). Corporate payout policy and credit risk: Evidence from credit default swap markets. Management Science forthcoming. https://doi.org/10.1287/mnsc. 2020.3753.

Wang, Zigan, Qie Ellie Yin, and Yu. Luping. (2021). Real effects of share repurchase legalization on corporate behaviors. Journal of Financial Economics 140: 197-219. https://doi.org/10.1016/j.jfine co.2020.10.008.

Wu, Yufeng. (2018). What's behind smooth dividends? Evidence from structural estimation. The Review of Financial Studies 31 (10): 3980-4016. https://doi.org/10.1093/rfs/hhx119.

Publisher's note Springer Nature remains neutral with regard to jurisdictional claims in published maps and institutional affiliations. 